\title{
Innovative Surface Modification Procedures to Achieve Micro/Nano-Graded Ti-Based Biomedical Alloys and Implants
}

\author{
Jie Li ${ }^{1}$, Peng Zhou ${ }^{1, *}$, Shokouh Attarilar ${ }^{2, * \mathbb{C}}$ and Hongyuan Shi ${ }^{1}$ \\ 1 School of Aeronautical Materials Engineering, Xi'an Aeronautical Polytechnic Institute, Xi'an 710089, China; \\ 18792771967@163.com (J.L.); shy2008x@163.com (H.S.) \\ 2 State Key Laboratory of Metal Matrix Composites, Shanghai Jiao Tong University, Shanghai 200240, China \\ * Correspondence: pzhou1975@outlook.com (P.Z.); sh.attarilar@yahoo.com (S.A.)
}

Citation: Li, J.; Zhou, P.; Attarilar, S.; Shi, H. Innovative Surface

Modification Procedures to Achieve Micro/Nano-Graded Ti-Based Biomedical Alloys and Implants. Coatings 2021, 11, 647. https:// doi.org/10.3390/coatings 11060647

Academic Editors: Anton Ficai and Devis Bellucci

Received: 15 April 2021

Accepted: 21 May 2021

Published: 28 May 2021

Publisher's Note: MDPI stays neutral with regard to jurisdictional claims in published maps and institutional affiliations.

Copyright: (ㄷ 2021 by the authors. Licensee MDPI, Basel, Switzerland. This article is an open access article distributed under the terms and conditions of the Creative Commons Attribution (CC BY) license (https:// creativecommons.org/licenses/by/ $4.0 /)$.

\begin{abstract}
Due to the growing aging population of the world, and as a result of the increasing need for dental implants and prostheses, the use of titanium and its alloys as implant materials has spread rapidly. Although titanium and its alloys are considered the best metallic materials for biomedical applications, the need for innovative technologies is necessary due to the sensitivity of medical applications and to eliminate any potentially harmful reactions, enhancing the implant-to-bone integration and preventing infection. In this regard, the implant's surface as the substrate for any reaction is of crucial importance, and it is accurately addressed in this review paper. For constructing this review paper, an internet search was performed on the web of science with these keywords: surface modification techniques, titanium implant, biomedical applications, surface functionalization, etc. Numerous recent papers about titanium and its alloys were selected and reviewed, except for the section on forthcoming modern implants, in which extended research was performed. This review paper aimed to briefly introduce the necessary surface characteristics for biomedical applications and the numerous surface treatment techniques. Specific emphasis was given to micro/nano-structured topographies, biocompatibility, osteogenesis, and bactericidal effects. Additionally, gradient, multiscale, and hierarchical surfaces with multifunctional properties were discussed. Finally, special attention was paid to modern implants and forthcoming surface modification strategies such as four-dimensional printing, metamaterials, and metasurfaces. This review paper, including traditional and novel surface modification strategies, will pave the way toward designing the next generation of more efficient implants.
\end{abstract}

Keywords: titanium; surface modification; surface topographies; multifunctional surfaces; metamaterials; $4 \mathrm{D}$ printing

\section{Introduction}

Titanium (Ti) and its alloys as metallic biomaterials have found lots of application in the biomedical industry, especially for bone implants (dental and orthopedic) [1,2]. This phenomenon is still growing. The utilization of Ti-based biomedical products reached about USD 45.5 billion in sales in 2014, so it is of great importance to make them as efficient as possible. Titanium with respective atomic number and weight of 22 and 47.86 is a transition element located in group IV and period four of Mendeleev's periodic table and, according to its room temperature atomic structure, it can be found as $\alpha$, near- $\alpha, \alpha+\beta$, metastable $\beta$, and stable $\beta$. The $\beta$ type Ti alloys are mostly preferred in biomedical applications because of their low elastic modulus (similar to natural bone) and high corrosion resistance [3-7]. In general, the reason behind this ever-increasing utilization of Ti-based materials in the biomedical field is related to their superb properties, including biocompatibility, non-toxic nature, good corrosion resistance, potential to have osteogenic reactions, high specific strength, low Young's modulus, lightweight, and high strength-to-weight ratio compared to steel and other metals [8-11]. As a result of these beneficial properties, from World War 
II until now, Ti has found lots of application in the biomedical field, especially in hard tissue replacements such as artificial bones, joints, dental implants, artificial hip joints [12], stents [13], scaffolds [14], and surgical devices.

An implant's surface has a crucial role in its reaction with peripheral live tissue since it is a substrate in which all biological reactions initially occur. As a result, it affects the performance of the implant, as well as its wettability and mechanical and chemical properties. The implant surface highly influences the ambient environment, having a significant effect on osteointegration [15,16], adhesion, and proliferation of osteoblast cells [12]. The implant surface is regarded as an artificial object from live tissue, and the first reaction of the body is to form foreign body giant cells by activated macrophages. Subsequently, the osteoprogenitor cells migrate onto the implant surface and differentiate into osteoblasts that finally produce bone [17]. It is reported that, generally, bone is separated from the implant's surface by a thin layer of non-mineral substances that prevent complete osteointegration [18]. Among other numerous reasons, this issue is one of the main reasons which justifies the need to use surface modification procedures. For example, in Ti implants, manufacturing techniques unfortunately lead to the formation of a layer with a poor condition that contains an oxidized, contaminated, stressed, and nonuniform surface that is not suitable for biomedical applications; hence it is of paramount importance to modify the surface. In addition, the surface must be accurately tailored in order to improve its mechanical bonding with peripheral tissue (bone, blood, muscle, etc.), biocompatibility, corrosion, wear, mechanical properties, roughness, and wettability $[19,20]$. For instance, Bauer et al. [21] showed the size-selective response of stem cells on anodic $\mathrm{TiO}_{2}$ and $\mathrm{ZrO}_{2}$, in which the cell adhesion and spreading were improved for $\mathrm{TiO}_{2}$ nanotube diameters in the range of 15 to $30 \mathrm{~nm}$, with a significant decrease in diameters higher than $50 \mathrm{~nm}$. Additionally, Park et al. [22] proved the relationship between nanotube diameter and cell fate, and reported that the proliferation, adhesion, and differentiation of stem cells are highly dependent on nanotube diameter. By considering the crucial role of surface condition, up to now, various surface modification techniques have been introduced [23] and practiced, leading to different surface topographies and properties, each of which has its characteristics and applications, and which is intended to be used in a specific location in the body. These methods can be categorized from different aspects such as type of method or resultant topographical size. Figure 1 briefly illustrates the surface modification procedures according to the type of method, but this paper aims to describe them from a structure size point of view.

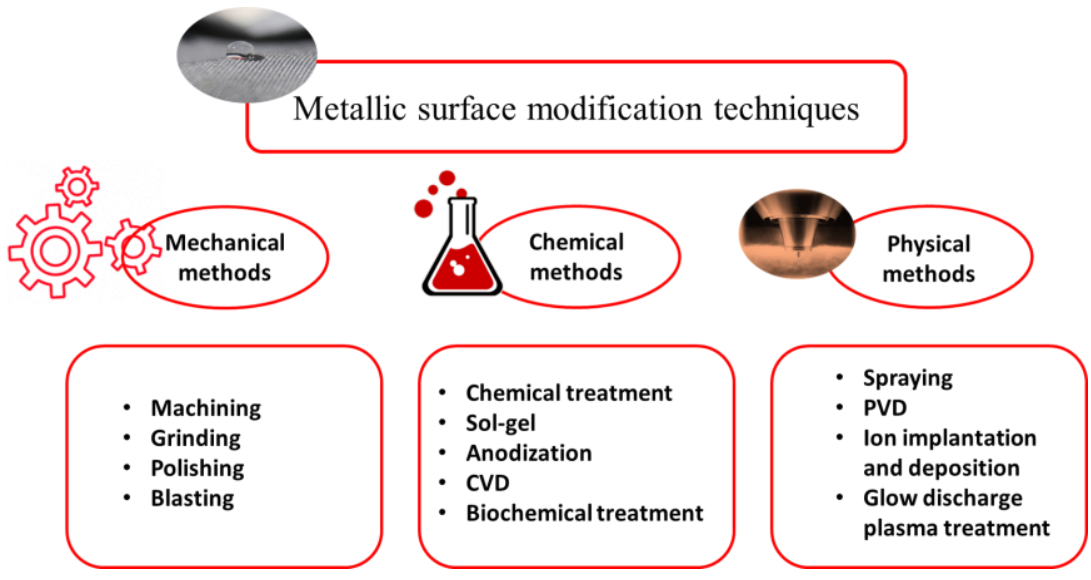

Figure 1. Metallic surface modification classification according to the type of technique.

An implant's surface can be modified through mechanical methods such as machining [24], grinding, polishing, blasting, and attrition [25]. In mechanical methods, the surface is modified by mechanical actions involving physical and attrition treatment, shaping, and removing the surface material. The objective of these methods is to achieve a certain 
type of roughness and topographies and eliminate the contaminations and oxide layers by removing the surface [26]. Recently, some severe plastic deformation techniques as mechanical methods have also been used to fabricate grain-refined surfaces and enhance the overall performance of biomaterials [27-31]. If the modification method involves chemical reactions, it is classified under chemical surface modification procedures [32]. The chemical techniques include anodic oxidation, sol-gel, chemical vapor deposition (CVD), biochemical modification, acidic, alkaline, and hydrogen peroxide treatment $[33,34]$. In the case of applying resistance heating, electron beam, laser, or electrical discharge in a vacuum, and of thermal, kinetic, and electrical energies, rather than chemical reactions, the modification method is classified under physical procedures. These physical modification techniques include thermal spraying, physical vapor deposition, ion implantation, and glow discharge plasma treatment.

Previous studies indicate that macro, micro, and nano-structured surface morphologies in implant surfaces can have pivotal effects on biocompatibility, bioactivity, osteogenesis, bone formation, and integration $[35,36]$. It was proven by many scholars that micro/nano-structured surfaces could improve biocompatibility [37], cell adhesion and proliferation, filament orientation, and even gene expression [38], as well as alkaline phosphatase (ALP) activity, cell mineralization, and osseointegration [39]. Some of these micro/nano-structures, in addition to maintaining biocompatibility and osseointegration, can have bactericidal properties [40]. They can even be used in drug loading applications [41,42], having the potential to be used as multifunctional techniques. It is known that high aspect ratio topographies are bactericidal with high effectiveness, which was numerously proven in Ti material [43,44]. Nanotube formation on Ti can be considered as the multifunctional option, providing biocompatibility, drug loading, and bactericidal effects. López-Pavón et al. [45] loaded the anodically produced nanotubes (on Ti-24Zr$10 \mathrm{Nb}-2 \mathrm{Sn}$ alloy) with gentamicin. The higher length and diameters of nanotubes leads to better a performance of drug loading, with a high percentage of gentamicin release. The micro/nano-scale variations in topology influence the antioxidant characteristic of the implant, as they can affect the oxidative stress microenvironment, enhancing or debilitating osteoinductive ability $[46,47]$. In this regard, for the first time, Ma et al. [48] reported that nano-structuring of the Ti surface through acid etching and anodic oxidation produces various topologies in which micro/nano-structures have superior oxidative stress resistance toward smooth and small nanotubes. By considering this brief introduction, it is clear that surface topographies are of significant importance in biomedical applications and investigations. In this regard, up-to-date and innovative surface modification methods and procedures are crucial in implant design and industry. These novel technologies will pave the way toward achieving a new generation of Ti implants with superior and multifunctional properties, leading to enhanced quality of human life and even decreased economic burdens on society.

\section{Surface Characteristics for Biomedical Applications}

\subsection{Roughness and Wettability}

The surface condition has a significant effect on numerous tissue reactions; it can influence cell proliferation and differentiation [49], protein adsorption [50], osseointegration, etc. In this regard, surface characteristics such as roughness, chemical composition, energy, wettability, biocompatibility, and bactericidal should be thoroughly studied and investigated. Osseointegration, as a direct structural and functional bonding between implant material and bone, is dependent on roughness; the surfaces with higher roughness and waviness can improve osseointegration [51]. It was seen that, in dental implants, rough surfaces have enhanced bone fixation, and they have higher bone-to-implant contact (BIC) value compared to commercially available implants [52], though the rougher surfaces compared to smoother ones have superior bone fixation [53]. Tailoring the surface of the implant with increased micro/submicron-scale roughness with sizes comparable to natural tissues and cells can lead to better osteoblast differentiation and production of local factors [54], with 
enhanced BIC value in vivo [55] and improved wound healing [49]. Nanorough surfaces with similar features to cell membrane receptors and proteins have a crucial role in improving the performance of the implant and osseointegration. Bone-implant surface interaction at various roughness and topographical conditions is schematically shown in Figure 2. Macroscale features can maintain a suitable mechanical fixation, while micro/submicron features can favorably interact with cells and osteoblasts. In a nanoscale condition, in addition to previous factors, the cell membrane receptors, integrins, and proteins are involved and enhance the overall quality of osseointegration and other biological reactions between bone and implant [56].
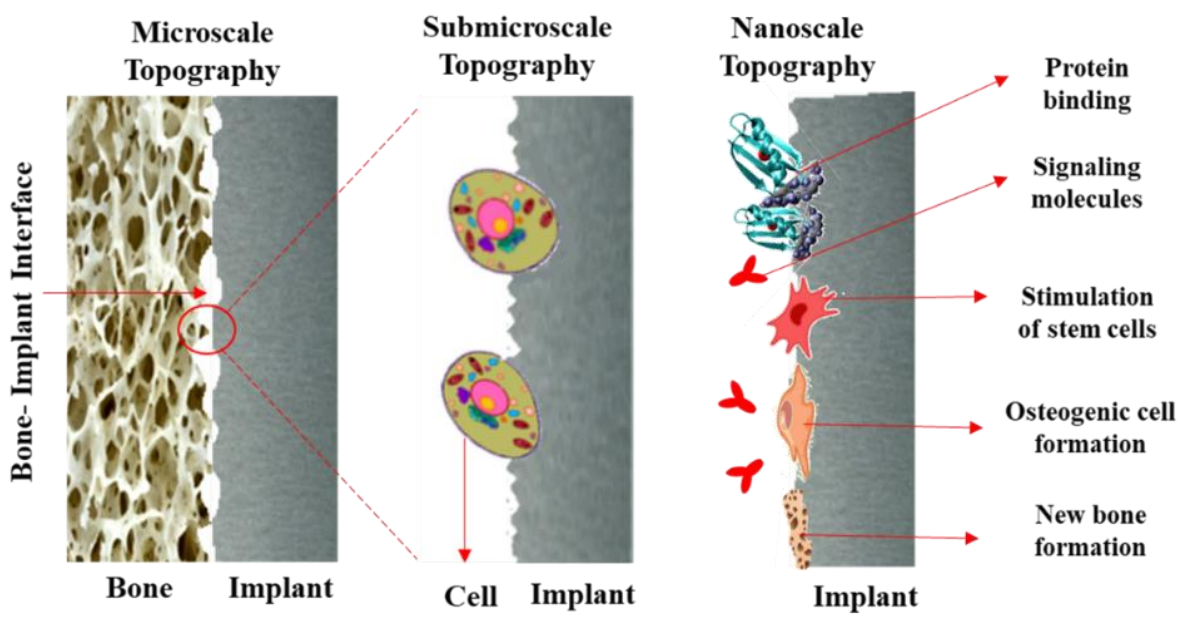

Figure 2. Bone-to-implant surface interaction at various roughness and topographical conditions.

Based on the roughness value, surfaces are classified into four categories: (1) smooth surfaces with Sa less than $0.5 \mu \mathrm{m}$ can be found in abutments of oral implants; (2) slight roughness with Sa in the range between 0.5 and $1.0 \mu \mathrm{m}$ in acid-etched samples and Astra Tech implants; (3) moderate roughness with Sa between 1 and $2.0 \mu \mathrm{m}$, which comprises nearly all modern implants, such as the Astra Tech, TiOblastTM, Nobel TiUnite, OsseoSpeedTM, Straumann SLA, and Dentsply Cellplus; (4) rough surfaces with a Sa higher than $2 \mu \mathrm{m}$, which are plasma-sprayed samples and Dentsply Frialit implants [57]. Since surface roughness is a critical factor modulating osteoblastic function, the optimum value should be determined, and the implant will be tailored according to it. Mustafa et al. [58] investigated the effect of various surface roughness values on the attachment, proliferation, and differentiation of cells on the Ti implant surface. They found out that the proliferation and differentiation of human mandibular bone cells are enhanced by increasing the surface roughness of the titanium implant. According to Rønold et al. [59], an optimal surface roughness ranges between 3.62 and $3.90 \mu \mathrm{m}$ for bone attachment. It should be mentioned that acid-etched surfaces and Ti coating are the most preferred ways to gain an optimum surface roughness to improve an implant's performance [60].

Wettability, as a tendency of one fluid to spread on or adhere to a solid surface, has a substantial impact on biological interaction between the implant surface and peripheral tissue, and affects protein adsorption phenomenon and cell adhesion [61]. Figure 3 schematically illustrates the wettability behavior on various Ti surfaces; the nanostructures have a more wetted area than the Ti-foil with the smooth surface because of liquid penetration. This better wettability in nanostructures is an advantageous characteristic in biomedical applications. 


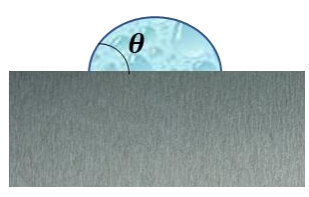

Ti substarte

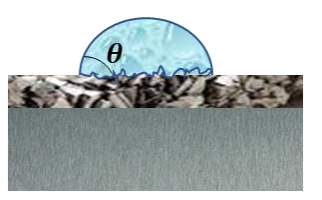

Nanopores

Absorbing solution

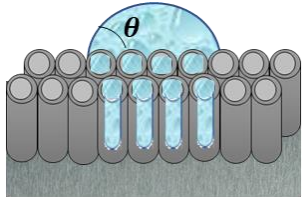

Nanotube

Absorbing solution

Figure 3. Wettability in Ti Nanostructures.

\subsection{Biocompatibility, Osteogenesis, and Bactericidal Effects}

Biocompatibility can be defined as the capability of the material to display a healthy and proper host response and, in this context, the surface condition of materials is highly influential. The biocompatibility of Ti implants is associated with their oxide layer's ability to react with the peripheral environment, water ions, and serum proteins [62]. It was demonstrated that acicular-shaped oxides and topographical features on the surface are more toxic and noncompatible compared to equiaxed ones, and the surface potential can affect the biocompatibility of the implant [63]. In addition, roughness and surface topography can alter cellular behavior, platelet and osteons activation, and protein adsorption, finally changing the material's biocompatibility. Hydrophobicity is another factor that controls biocompatibility, since it determines the type, amount, and binding condition of proteins [64]. In this regard, it is believed that hydrophilic surface features are more compatible and safer compared to the hydrophobic ones, and even lead to better bone integration in Ti implants [65]. The size of surface features can also affect the biocompatibility of implants; for example, in pits with a diameter higher than $25 \mu \mathrm{m}$, cells migrate inside and settle there $[66,67]$ or spread them out to fill the pit gap [68]. It was shown that fibronectin has higher adsorption in shallow pits and surface topography can affect the fibronectin distribution $[69,70]$. Overall, the biocompatibility response of an implant can be governed by its surface condition.

The term osteogenesis refers to the development and formation of new bone tissue by cells named osteoblasts, and osteointegration is known as the direct and through contact between bone and implant. Figure 4 schematically illustrates the osseointegration procedure on metallic implants, which includes three phases [71]. In the first phase after implantation, the surface of the implant is surrounded by blood, biomolecules, proteins, glycoproteins, and lipids, establishing a transitory bioactive film. After about one month, in phase two, the bone tissue is slightly absorbed around the implant, and proliferation and differentiation of osteon cells begin, leading to mineralization. After about three months, the implant surface is covered by many osteoblasts and osteoclasts that gradually mature, leading to progressive osteointegration. Many surface-related variables can impact the osteogenesis and osteointegration conditions of implant material, including wettability, roughness, surface chemistry, energy, etc. [72]. Any failure in proper osteointegration and osteogenesis leads to implant failure and many costs to both patient and the medical system; hence, it is of vital importance to avoid such errors. In this regard, titanium can be considered as a bioinert material with proper bone contact under osteo-permissive conditions; it is better than bio-tolerant materials and, unfortunately, more feeble than bioactive materials, so its surface can be purposefully modified in order to become bioactive. Surface topography and roughness can be accurately tailored to compensate for poor osteogenesis and osteointegration conditions [73]. The optimum roughness is about 1 to $1.5 \mu \mathrm{m}$, which maintains suitable bone-to-implant fixation [72]. Lossdörfer et al. [74] showed that, by increasing the surface microroughness, the osteoblast proliferation diminishes while differentiation increases since, in microrough topographical features, osteoblasts secrete some biological factors which improve osteoblast differentiation and diminish osteoclast activity and formation. Surface modification techniques can be incorporated to actively control the bone marrow-derived mesenchymal stem cells' (BMSCs) fate as one of the critical variables in osteogenesis. In this regard, surface technologies such as anodization, micro-arc oxidation, sol-gel, and ion implantation can improve BMSCs' differentiation [75]. Additionally, 
titania nanotubes (TNTs) are considered as favorable surface modification strategies to improve osteogenesis and osteointegration [76]. Shen et al. [77] reported that TNTs can improve osteogenic self-differentiation and decrease early inflammation of macrophages; the overall cellular response of mesenchymal stem cells (MSCs) and macrophage behavior can be well regulated by proper utilization of TNTs. In another study [78], it was shown that TNTs on Ti surface show the best osteogenesis response in comparison to a micro-scale case (sand blasted-acid etched topography) and a nano-scale case (hybrid sand blasted-acid etched), proving that nano-scale TNTs have the best surface topography for increasing clinical performance.
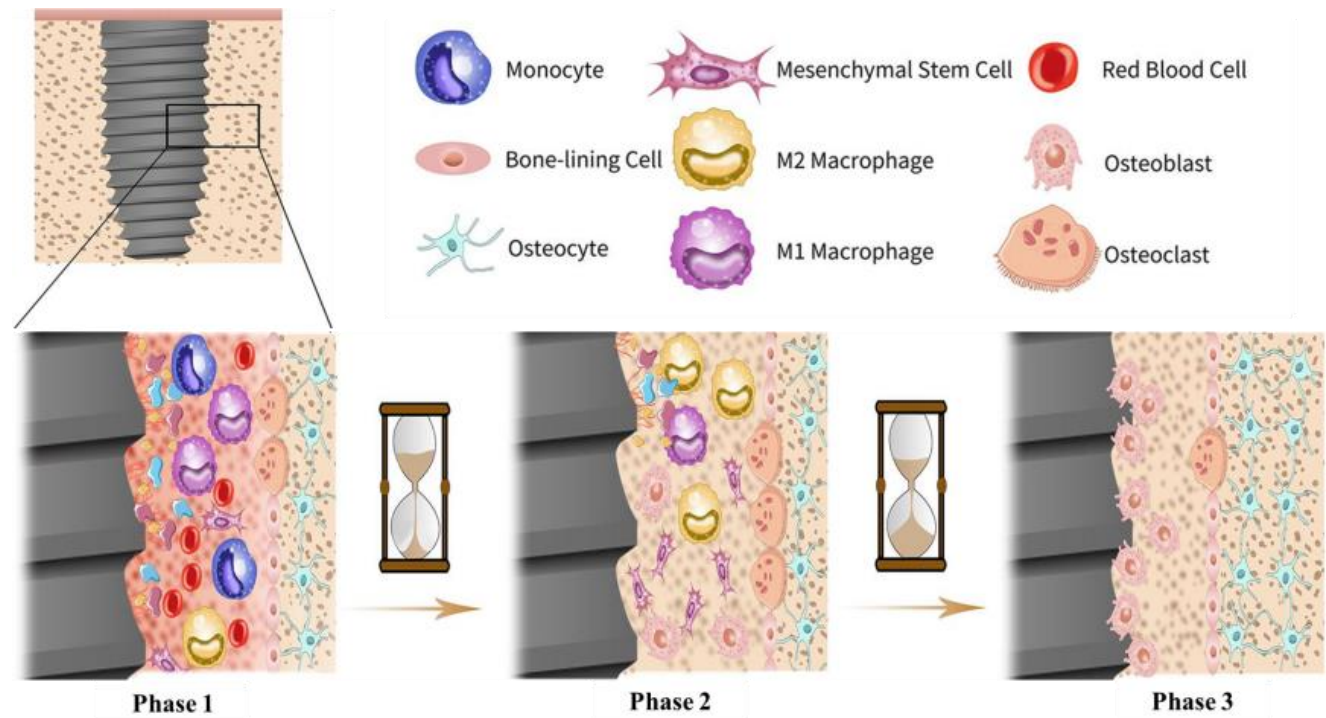

Figure 4. The osseointegration procedure on metallic implants [71]. In phase 1, the surface is surrounded by blood, biomolecules, proteins, glycoproteins, and lipids, establishing a bioactive film. In phase 2, the initial bone tissue absorption is begins simultaneously with osteon cells' proliferation and differentiation, leading to mineralization. In phase 3, the surface is covered by osteoblasts and osteoclasts, causing progressive osteointegration.

By two bacteriostatic and bactericidal strategies. Figure 5 schematically illustrates The bactericidal effect is an action that prevents the growth of bacteria and keeps them in a stationary phase of growth. A bactericide material can also kill bacteria. As is known, implant-related infections are among the most serious problems and issues in implant surgeries, which lead to failure and cause costly subsequent surgeries [79]; hence it is of crucial importance to resolve them. Mainly, two forms of bacteria are responsible for infection-related issues, Staphylococcus aureus (S. aureus) [80] and Staphylococcus epidermidis (S. epi.) [81]. Surface modification techniques are highly beneficial in the prevention of biofilm formation and infections, and can be achieved by designing antimicrobial surfaces which are able to avoid any pathogen spread and material deterioration these two mechanisms. These bactericidal surfaces actively prohibit the initial adhesion of living planktonic microbial cells that are created through the killing of bacteria or exorcising the approaching microbial forms. These antibacterial effects can be attained by various methods (physical, chemical, physicochemical, coatings, etc.) and in different scales (macro, micro, nano, atomic, molecular, and textural). In this regard, there are many types of antibacterial macromolecule [82-84], such as inorganic bactericidal metallic elements silver, copper, zinc, etc. [85-87]. 


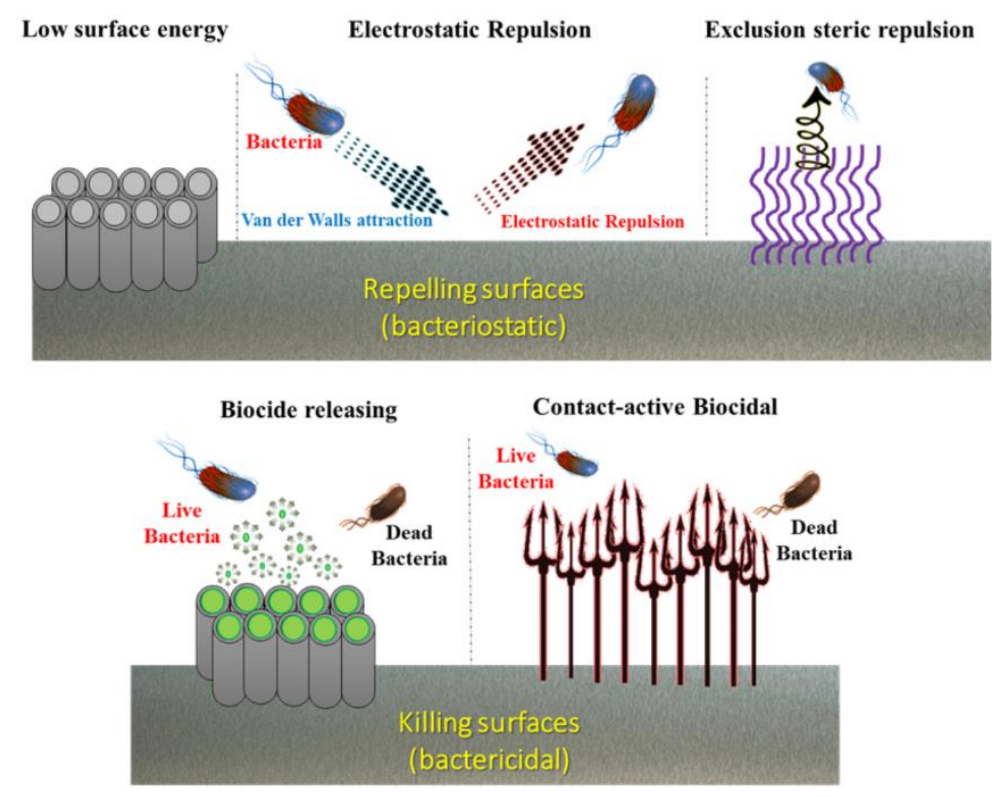

Figure 5. Schematic illustration of two surface modification strategies (bacteriostatic and bactericidal) in designing bactericidal surfaces.

\section{Surface Modification Procedures}

\subsection{Macro-Grade Modification}

Macro-scale surface treatments warrant the generation of a rough structure on the surface of titanium implants, and therefore improve their biological performance and osseointegration. Moderate roughness, with the average (Sa) ranging from 0.5 to $2 \mu \mathrm{m}$, is suitable for bone ingrowth in dental and orthopedic implants [88]. In this regard, many techniques with the capability to produce macro-rough surfaces have been introduced, such as etching techniques through acid etching [89,90], sandblasting [91,92], three-dimensional printing (3DP) [93], and laser surface texturing [94].

\subsubsection{Acid Etching and Sandblasting Techniques}

In the surface modification of Ti in biomedical applications, acid etching is of substantial importance, since it can generate fine-rough $(1-3 \mu \mathrm{m})$, rough $(6-10 \mu \mathrm{m})$, and macrorough $(10-30 \mu \mathrm{m})$ surfaces. Acid-etching can considerably improve early endosseous integration and implant stability; as has been shown, dual acid-etched Ti implants with macro-roughness in the range of 10-30 $\mu \mathrm{m}$ could effectively enhance bone anchorage and early osseointegration in rabbit models [95]. The dual effect of acid etching on cell behavior and mechanical properties was studied by Wang et al. [96], who reported that acid etching in hydrochloric acid could produce very rough surfaces (up to $3.7 \mathrm{~mm}$ roughness value), which led to considerable improvements in osteoblast cell adhesion and proliferation. It was seen that roughness is dependent on etching duration and, by increasing etching time, the surface roughness incremented while its yield strength diminishes. As such, a balance between cell response and strength should be considered. Figure 6 shows the immunofluorescence micrographs of osteoblast attachment on Ti samples with various etching durations. The optimal etching time is about $60 \mathrm{~min}$, showing both favorable cell response and strength. 

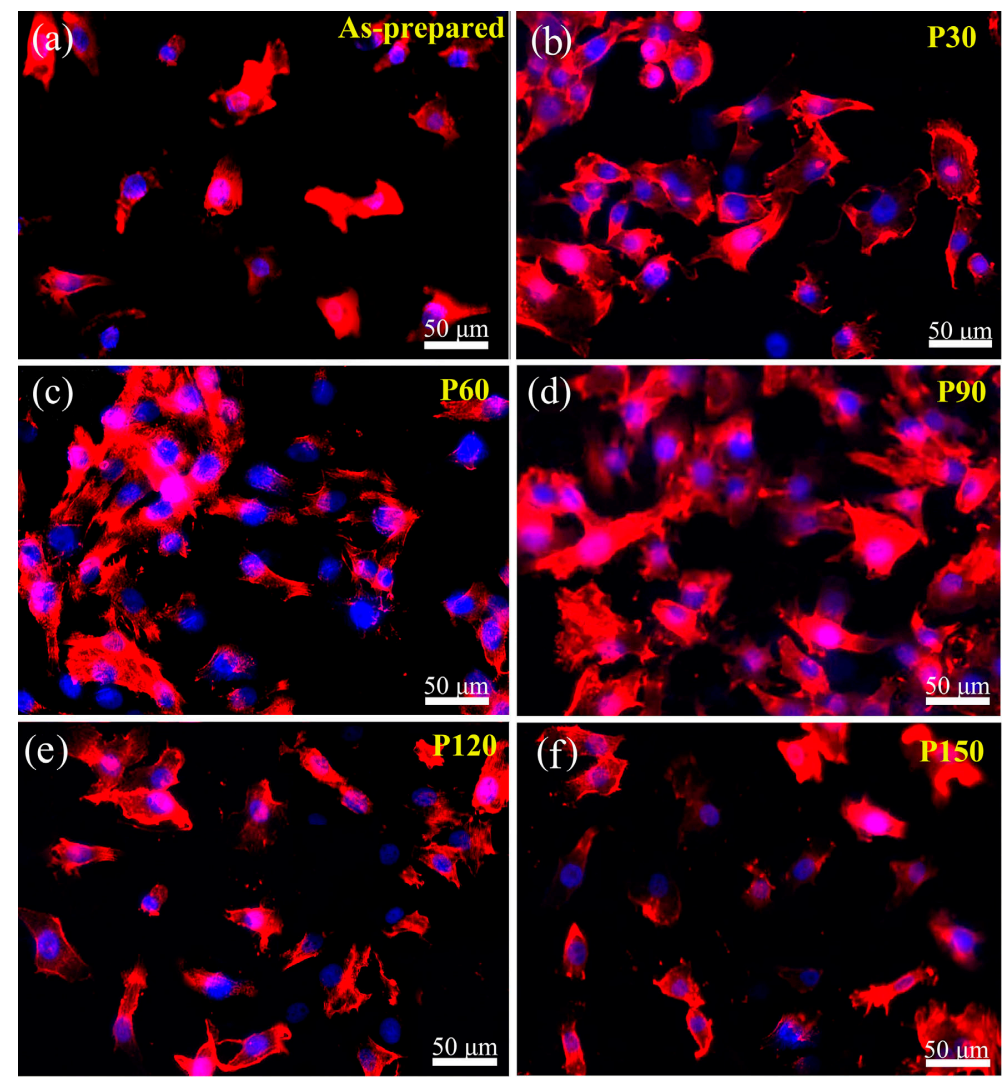

Figure 6. The immunofluorescence micrographs of osteoblast attachment on Ti samples after one-day of incubation. Rhodamine-phalloidin was used to stain the actin filaments and DAPI was utilized to stain cell nuclei. (a) Control sample without etching, (b-f) after etching for 30, 60, 90, 120, and $150 \mathrm{~min}$, respectively [96] (reproduced with permission number: 5066331116663, John Wiley and Sons).

One of the most infamous and oldest modification techniques of Ti implants is sandblasting, in which the pressurized abrasive material is volleyed onto the surface of the implant so that the surface becomes rough and its osseointegration improves. It was shown that acid-etched surfaces have higher roughness magnitudes than sandblasted ones. Sandblasting with alumina powders can be utilized in order to clean and achieve microretentive topography and increase surface area. Sandblasting can also increase the bone anchorage by up to $50 \%$ [97]. Sandblasting by hydroxyapatite particles can produce bioactive surfaces, stimulate bone apposition, and facilitate the healing process [98]. Uncontrolled sandblasting may induce unfavorable surface defects and reduce the endurance limit of the implant [99], so the variables in the process should be thoroughly considered and controlled. Li et al. [100] showed that a modified sandblasting treatment can even lead to improved mechanical properties and considerably enhance the shear strength at dental implants. Figure 7 shows a SEM micrograph of a sandblasted Ti sample with aluminum oxide and an untreated sample. While sandblasting is an age-old method, some innovative mediums, post-treatments, and variables are introduced and experienced. In this regard, some complex blasting mediums with a mixture of $\mathrm{Al}_{2} \mathrm{O}_{3} / \mathrm{NaAlSi}_{3} \mathrm{O}_{8} / \mathrm{ZrO}_{2}-$ $\mathrm{TiO}_{2}$ were used, and were shown to have improved bonding properties, with obvious "micro-vaccination" regions with enhanced adhesion of porcelain (bond) in titanium-dental porcelain interface [101]. 

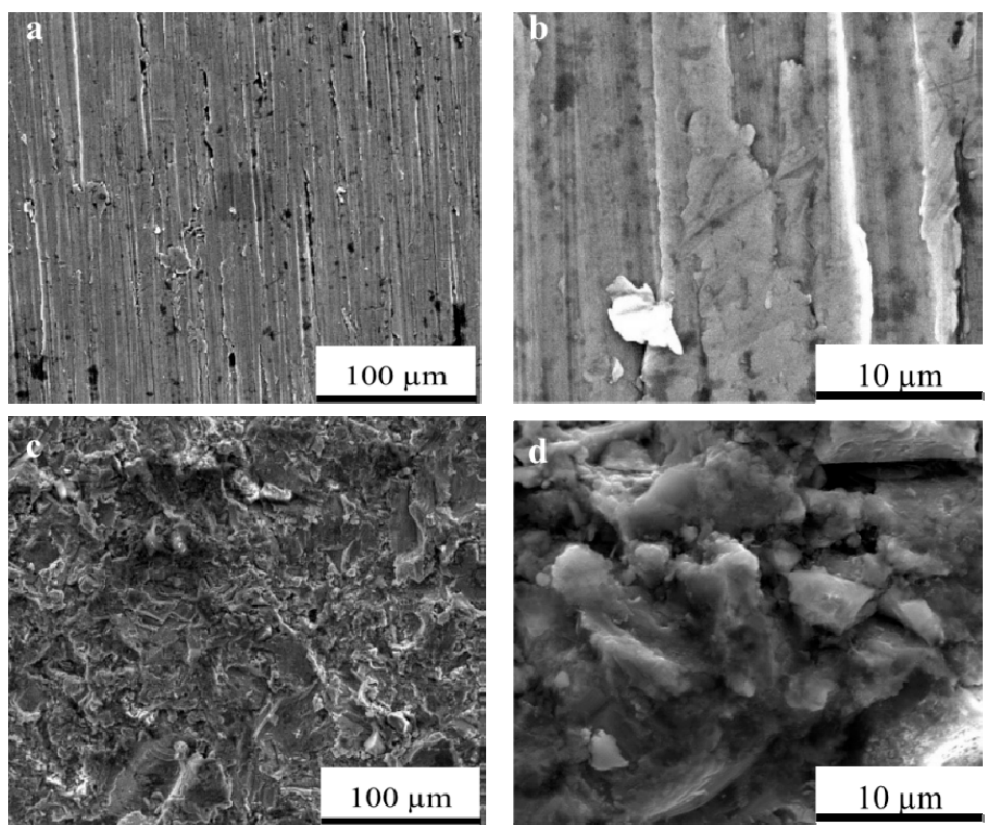

Figure 7. A SEM micrograph of Ti samples: Untreated samples (a) $1000 \times$ and (b) 10,000 $\times$ magnification; sandblasted samples by aluminum oxide (c) $1000 \times$ and (d) 10,000 $\times$ magnification [102] (reproduced with permission number: 5071110018393, AIP Publishing).

\subsubsection{Three-Dimensional Printing (3DP)}

Three-dimensional printing (3DP), also known as additive manufacturing (AM), is a revolutionary procedure affecting all parts of science, industry, and even human life. Due to the very promising benefits of 3DP, its use in medical implants is expected to increase dramatically. These unique advantages include its great potential in the production of porous and complex shapes, even with intricate internal structures. In addition, it has an economic nature and can be utilized in mass production. Other advantages are repeatability, rapid production, and simple design. The most beneficial aspect of 3DP is its great potential in manufacturing patient-specific implants with multifunctional surfaces [103]. Another positive point of $3 \mathrm{DP}$ is that it has many diverse techniques, enabling us to use many types of materials, from organic to inorganic compounds, hydrogels, polymers, and metals. Another positive aspect of these numerous 3DP techniques is their ability to use a variety of curing systems according to specific conditions and needs in and intended application, which is a fundamental feature of the biomedical industry [103]. Figure 8 lists the most popular 3DP methods and their respective curing and deposition systems.

The resultant surface features after 3DP are mainly dependent on the deposition technique; for example, the mean roughness value after selective laser melting (SLM) is lower than electron beam melting (EBM), since the laser spot size is smaller than the electron beam. In addition, the SLM technique can produce thinner layers and utilize smaller powder sizes [104]. Many studies concluded that the production of Ti implants through 3DP is highly beneficial in improving cell responses and osseointegration $[105,106]$. Sirvas et al. [107] produced a 3D printed porous Ti-6Al-4V scaffold (extrusion-based method) with an average roughness of $\sim 5 \mu \mathrm{m}$ and comparable mechanical properties to natural bone due to a porosity of $\sim 58 \%$ and a pore size of $\sim 500 \mu \mathrm{m}$. This 3D printed sample shows considerable bone in-growth and in vivo on-growth, and complete filling of pores with the bone after 8 weeks of implantation in the rabbit model; Figure 9 shows the bone in-growth of this 3DP scaffold in the rabbit model [107]. However, the osteogenesis of 3DP manufactured $\mathrm{Ti}$ and its alloys are not satisfactory due to biological inertia issues, and should be improved by secondary procedures. In this regard, Wang et al. [108] utilized hydrothermal and alkaliheat treatment to further improve osteogenic differentiation and accelerate osseointegration. They reported a new bone formation and rapid osseointegration in rabbit models due to 
secondary surface modifications, leading to the generation of micro/nano-topography instead of the initial macro-graded topography in Ti-6Al-4V implants. Additionally, Gulati et al. [109] utilized an anodization procedure to generate dual micro/nano-scale topography on 3DP Ti-6Al-4V orthopedic implants. The results showed an enhanced cellular function, osseointegration, and improved adhesion of osteoblasts.

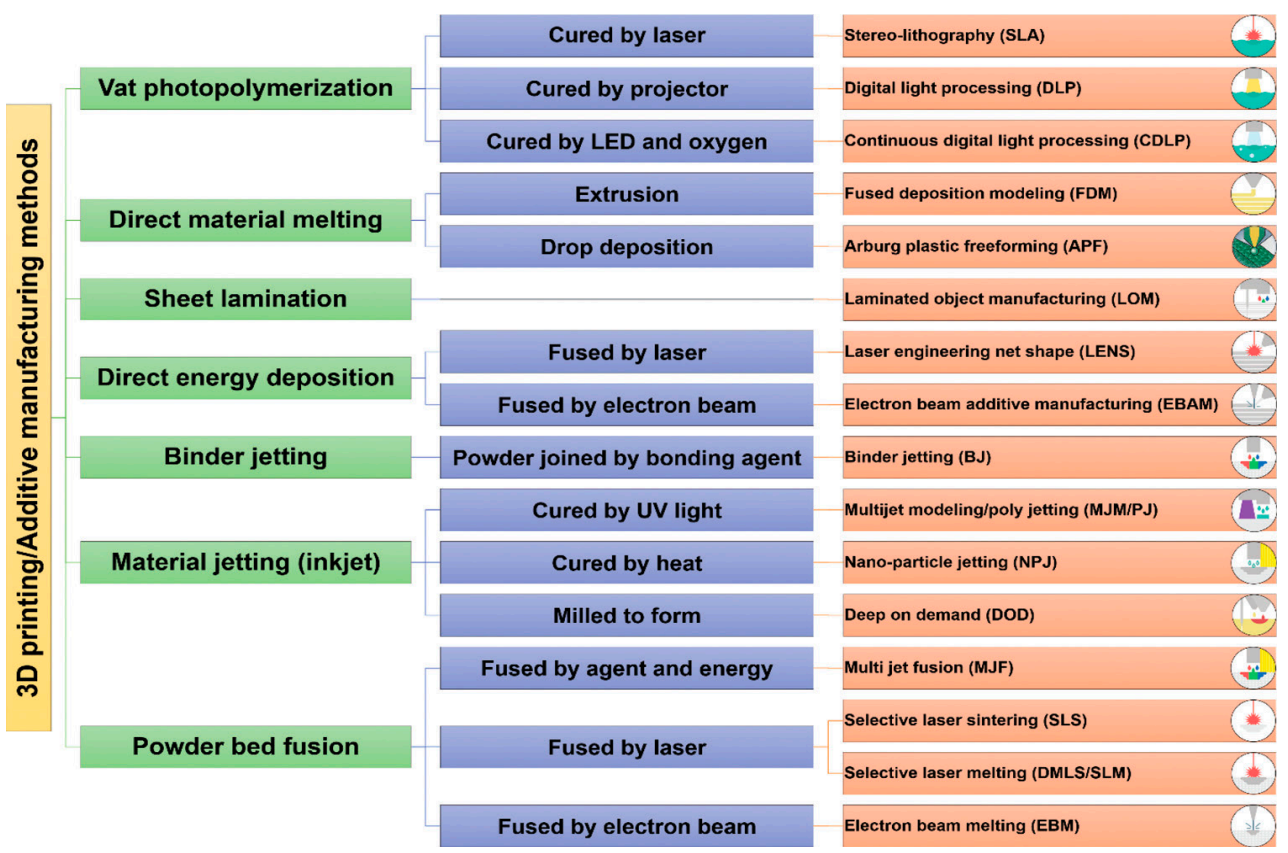

Figure 8. The most important 3DP methods and their corresponding curing and deposition systems [103].
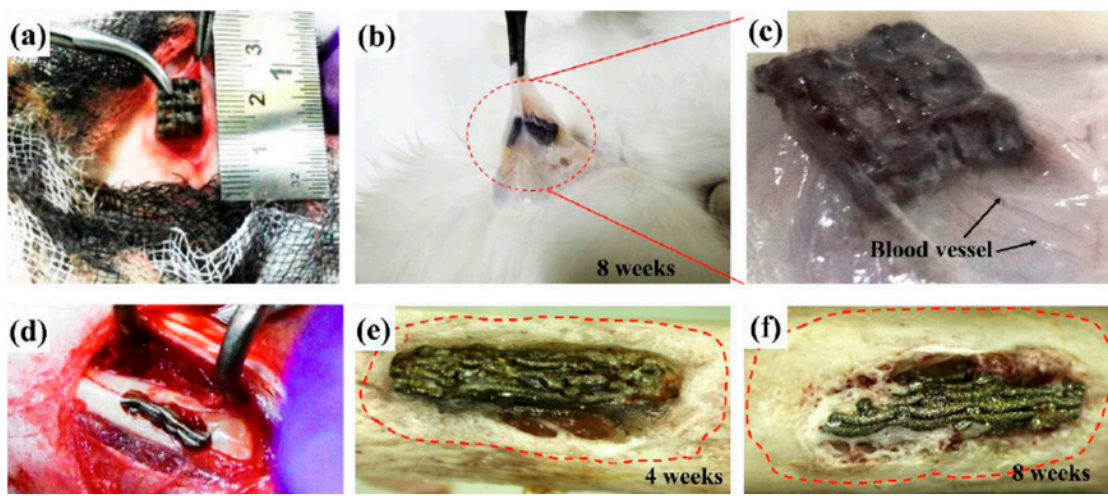

Figure 9. (a) Subcutaneous implantation of a 3DPed porous Ti-6Al-4V scaffold in rabbit model; (b) scaffold in the rabbit tissue after 8-week implantation; (c) magnified view of the circled region in (b), showing the tissue and blood vessel formation around the scaffold; (d) scaffold implantation in rabbit's femur and bone in-growth around the scaffold after (e) 4 weeks and (f) 8 weeks [107] (reproduced with permission number: 5071080659903, Elsevier).

\subsubsection{Laser Surface Texturing (LST)}

Laser surface processing development over the past 40 years has great potential in terms of surface modification, with numerous promising advantages in the biomaterial field. Laser-based methods are able to modify various surfaces, from macro to nano-scale topographies, and an important aspect of laser utilization is that there is not any need for direct contact, which prevents contaminations. Laser processing can manufacture Ti surfaces with improved tribological, corrosion, and erosion-resistant characteristics [110]. In addition, these techniques are clean, rapid, and easy-automated, with a surface patterning 
ability and a capability for application on any intricate and complex-shaped samples. In laser-based surface modification techniques, the interaction of an energetic laser beam with a surface induces craters. Diverse topographies and patterns with various dimensions can be generated by controlling the craters' dimensions, depending on laser spot size and mutual interactions of the laser beam, plasma, and surface [111].

Laser surface texturing (LST) is a process that renovates a material's surface properties mainly by modifying its texture and roughness; hence, it can be effectively utilized in implants and biomedical applications. The surface morphology of the Ti sample after the LST method is shown in Figure 10, illustrating the formation of both micro-nano hierarchical structure (MNHS) and the laser-induced periodic surface structures (LIPSS) [112]. The average micropillar dimensions are, respectively, about 20.45, 12.67, and $33.11 \mu \mathrm{m}$ in length, width, and height. As can be seen in Figure 10, the micropillars' tops are covered with laser-induced nanoparticles, and top caps are surrounded by nanoripples that are organized according to the laser's direction. In general, LST of Ti in biomedical applications is applied under short-pulsed laser conditions [113]. Laser-based methods can effectively produce micro and nano-scales, but macro-grade modifications need much longer processing times compared to micro and nano conditions. The patterning ability in LST methods is crucial, since it can affect cellular response and bonding strength of an implant to tissue; it has also been shown that novel textures by using various patterning plans lead to the formation of diverse topographies, influencing the wettability of the surface, cell integration, and coefficient of friction against bone [94,114]. Pou et al. [113] suggested avoiding high energetic and short pulses in LST to prevent crack formations, and claimed that using an Nd:YAG laser is more appropriate for Ti modification, resulting in more regular shapes and fewer splashes without any variations in the chemistry of the surface. Cunha et al. [115] reported that femtosecond LST processing leads to the formation of nanopillars and laser-induced periodic surface structures (LIPSS) on Ti substrate, which enhances hydrophilicity and surface energy. These topographies are shown to be effective in the reduction of Staphylococcus aureus adhesion and biofilm formation on Ti surfaces.

\subsection{Micro-Grade Modification}

\subsubsection{Sandblasting Acid Etching (SLA) Techniques}

Sandblasting acid etching (SLA) is a surface treatment leading to improved topographies with enhanced osseointegration due to increased bone-to-implant contact (BIC). SLA is regarded as one of the most investigated and well-known methods for producing microrough surfaces. In this method, the sandblasted surface with macro-rough topography is followed by acid etching, which induces microroughness [91]. The SLA process can intensify the osseointegration rate by a combination of grit and acid etching that increases the roughness value on multiple levels. This improved surface with microroughness conditions encourages osteoblasts to proliferate and adhere to the implant surface, resulting in improved implant stability and a treatment time reduction. These SLA-treated implants provide a variety of benefits to patients requiring increased ossification [86]. The in vivo experiments of Buser et al. [87] on miniature pigs showed a considerably higher mean percentage of BIC and bone apposition in a chemical SLA Ti implant. Similar results were reported by Chiang et al. [116] showing the significant beneficial effects of SLA treatment on improving osseointegration, especially at the early stages of bone tissue healing. 

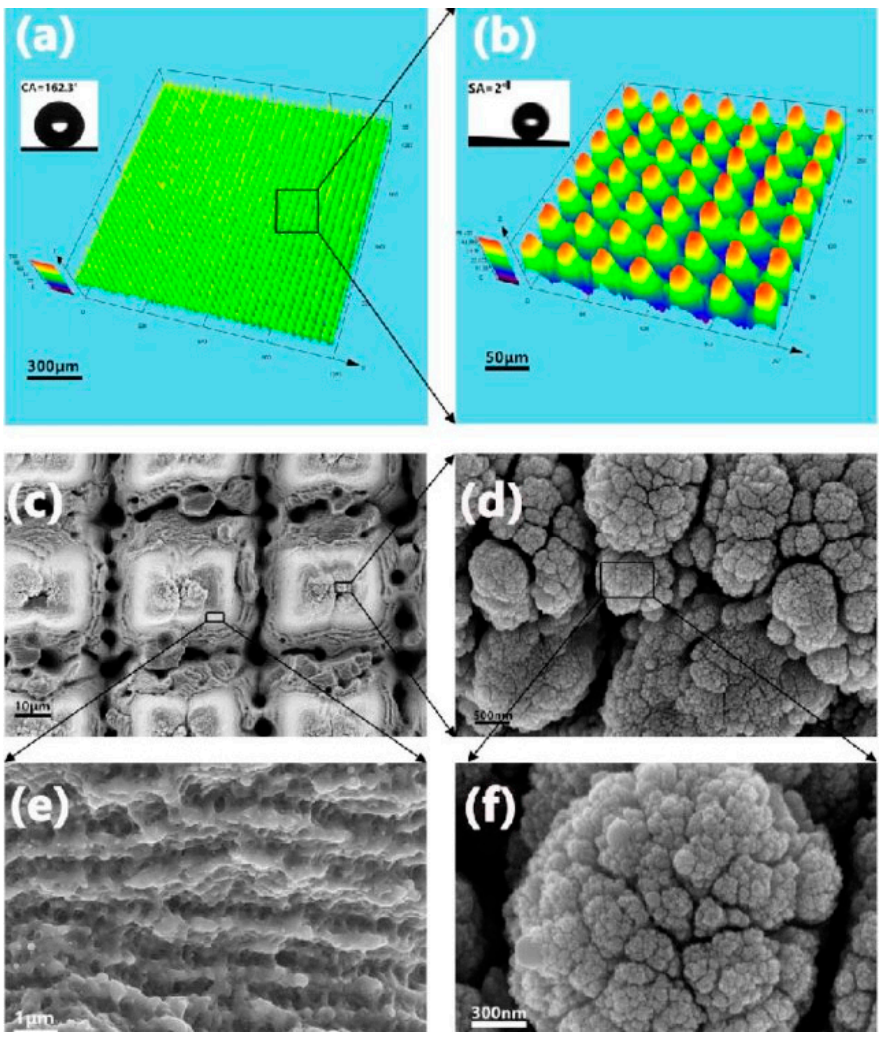

Figure 10. The LST processed Ti samples: (a) surface 3D profile, (b) magnified 3D profile, (c-f) SEM micrographs showing the LIPSS and MNHS topographies with the magnification of rectangular regions [112] (reproduced with permission number: 42, 3936-3939 (2017), Optical Society).

In addition to the traditional SLA method, current modern and complex procedures are proposed with the addition of other schemes to further improve the biological response of Ti implants. For example, Liu et al. [117] utilized a chemical scheme by $\mathrm{Cu}$ in addition to SLA treatment, and it was shown that $\mathrm{Cu}^{\prime}$ s addition to SLA-produced micro-submicron hybrid structures significantly improves the bactericidal effects toward oral anaerobic types of bacteria (P. gingivalis and S. mutans), and simultaneously enhances in vitro osteogenic and angiogenic gene expression. In vivo experiments confirm the ability of this combined technique for osseointegration improvement, showing enhanced peri-implant bone formation and favorable bone-binding. Additionally, these Cu-assisted SLA Ti samples, due to $\mathrm{Cu}$-induced antiinfection effects, led to a gain resistance toward bone resorption and improved osseointegration [117]. In this regard, Choi et al. [118] modified the SLA-treated Ti surface with strontium-containing nanostructures through wet chemical treatment, leading to multifunctional effects such as enhanced osteogenic capacity, improved osseointegration, immunoinflammatory macrophage cellular behavior, and early macrophage cell functions. In another study, Kim et al. [119] used Mg ion implantation via a vacuum arc source ion implantation method to further improve human mesenchymal stem cell (hMSC) response in an SLA-treated Ti sample; the results indicated favorable cell adhesion, ALP activity, and calcium accumulation, leading to improved osseointegration. Figure 11 shows these SLA- and Mg-ion-implanted SLA samples with rough and irregular morphology, with an average roughness value of $\sim 2 \mu \mathrm{m}$, which is not affected due to Mg-ion implantation. 

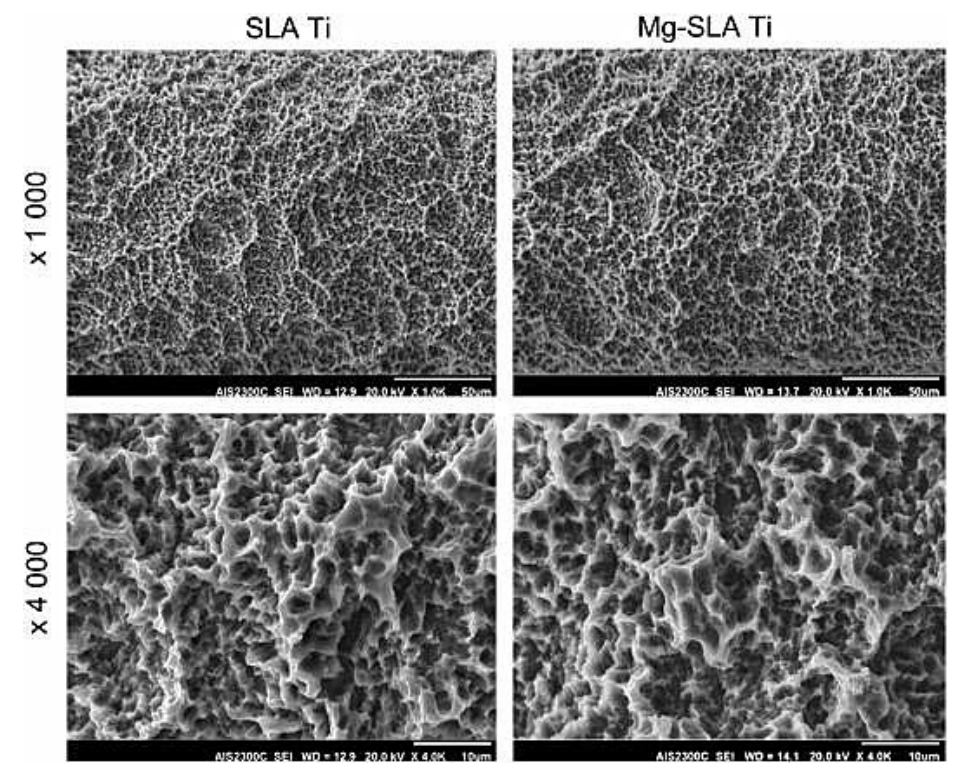

Figure 11. SEM micrograph of SLA-treated Ti samples and Mg-ion implanted SLA-Ti with 1000× and 4000× magnification [119] (reproduced with permission number: 5071100309175, Elsevier).

\subsubsection{Other Micro-Grade Methods}

One of the well-known methods to modify the surface of Ti implants is grit blasting, in which hard ceramic particles are shot via compressed air at a high velocity through a nozzle. The resultant surface roughness is dependent on the size of the ceramic particles $(\sim 100-300 \mu \mathrm{m})$, and they should be selected from biocompatible materials such as silicon oxide $\left(\mathrm{SiO}_{2}\right)$, aluminum oxide $\left(\mathrm{Al}_{2} \mathrm{O}_{3}\right)$, titanium oxide $\left(\mathrm{TiO}_{2}\right)$, zirconium oxide $\left(\mathrm{ZrO}_{2}\right)$, steel, and calcium phosphate composition [120]. One of the disadvantages of the grit blasting method is the issue of particles remaining on the surface, which are very hard to remove and which may release into the live tissue, leading to allergies and other biologically adverse effects [121]. Studies show that grit blasting can lead to improved BIC values in $\mathrm{Ti}$ implants. For example, Ivanoff et al. [122] proved that $\mathrm{TiO}_{2}$ blasting on Ti micro-implants leads to higher BIC values, while some other studies are syill confirming the promising effects of $\mathrm{Al}_{2} \mathrm{O}_{3}$ and $\mathrm{TiO}_{2}$ blasting [123]. The reported clinical studies claimed a high success rate of $\mathrm{TiO}_{2}$ grit-blasted Ti implants [105].

In addition to macro-grade surface modification, acid etching can also be used for micro-grade modification, in which surface roughening is performed by strong acids such as nitric acid $\left(\mathrm{HNO}_{3}\right)$, sulfuric acid $\left(\mathrm{H}_{2} \mathrm{SO}_{4}\right)$, hydrofluoric acid (HF), hydrochloric acid $(\mathrm{HCl})$, and other combinatorial acidic solutions. Acid etching procedures are able to produce surfaces with micro-pits with the size range of 0.5-2 $\mu \mathrm{m}$ [124], but acid etching can have some negative effects on the mechanical properties of the implant. Acid etching can stimulate macrophage activity and enhance cell proliferation and the pro-angiogenic response of endothelial cells, leading to increased BIC values, improved osseointegration, and better initial osteoblast anchorage [125,126]. Diomede et al. [127] showed a considerably improved biological response of dual acid-etched Ti samples, with resultant improved cell growth and adhesion, enhanced osteogenic and angiogenic events, as well as a clear osseointegration process. Additionally, Wang et al. [96] proved that acid etching by $20 \mathrm{wt} . \%$ $\mathrm{HCl}$ induces a remarkable enhancement of osteoblast cell adhesion and proliferation on the porous Ti.

\subsection{Nano-Grade Modification}

Nano-grade surface modification is of crucial importance, since human tissue morphology includes numerous nanostructures, such as natural bone, which has a hierarchy in terms of the macro-, micro-, and nano-scale structures, with a gradual transition between them [128]. The existence of micro and nanostructures can considerably affect the cell 
response and the initial bone formation around the implant material [129]; hence, recently, many attentions have been focused on the design of mixed micro/nano topographies with multifunctional properties through modern and innovative techniques [130-134]. These nanofeatures stimulate osteogenic activity and increase the adsorption of proteins, leading to rapid osseointegration and far better performance of implants [135-137]. A comparative study about the effect of micro and nanostructures on osseointegration of Ti implants proves the considerable superiority of nanostructures, with enhanced performance in the pull-out tests, direct bone apposition, and improved osseointegration [123]. Besides, these nanostructures facilitate the functionalization procedures paving the way toward fabricating bactericidal and anti-inflammatory surfaces [138]. Figure 12 shows the schematic of a $\mathrm{CeO}_{2}$-nanostructured Ti surface in which the formation of $\mathrm{CeO}_{2}$ nano-rods, -cubes, and -octahedrons can lead to strong antibacterial properties, and in which the nano-octahedrons showed the best anti-inflammatory response [138]. Nowadays, there are many methods for fabricating nano-grade surfaces on Ti implants. In addition to new and modern techniques, other macro and micro-grade methods can also be used in for nanomodification by changing the related variables. In this regard, some methods, such as grit blasting, acid etching, and SLA, were also classified in the nano-gradation group.

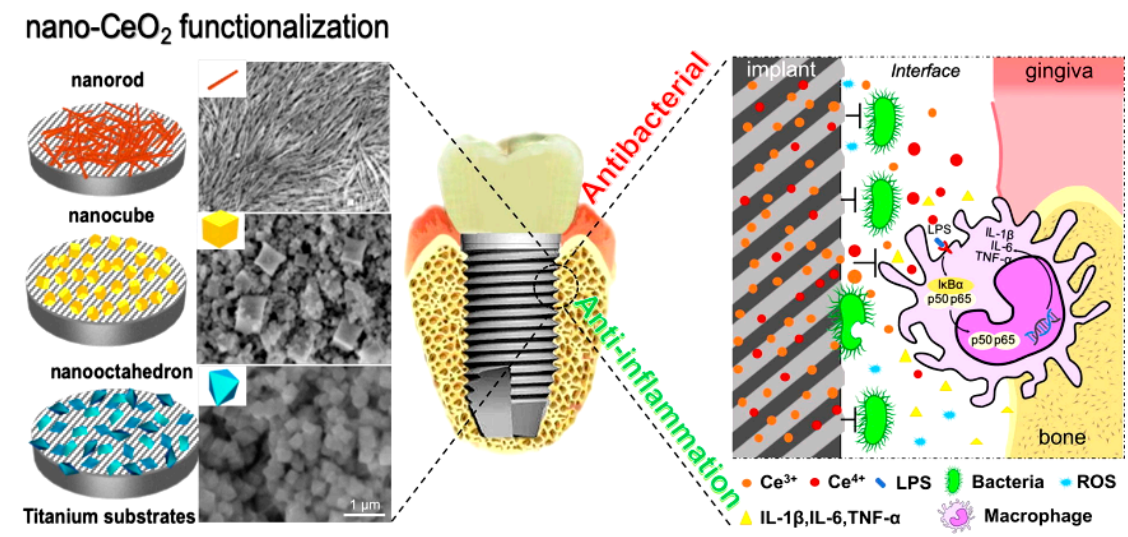

Figure 12. A schematic showing the Ti surface modification by nano- $\mathrm{CeO}_{2}$ (rod-CeO $2, \mathrm{cube}-\mathrm{CeO}_{2}$, octa- $\mathrm{CeO}_{2}$ ) for antibacterial and anti-inflammatory properties. Readers are referred to [138] (reproduced with permission number: 5071081046141, Elsevier) for more information.

\subsubsection{Electrochemical Modification}

Recently, much attention has been paid to the fabrication of nanopores and nanotubes with functional properties such as drug loading, being antibacterial, etc. These topographies can be easily attained through electrochemical methods such as anodization. Figure 13 shows the generation of various topographies, with related mechanisms on the metallic substrate by the anodization method. Briefly, anodization is an electrochemical technique in which an ordered oxide film is grown on a metallic sample connected to the anode of an electrochemical cell [139]. Charging the double electric layer at the metal-electrolyte interface generates the anodic oxide film. Subsequently, the dissolution of oxide film by the electric field leads to the formation of soluble salt consisting of an anion and metal cation in the electrolyte solution. Finally, the electrochemical reactions (oxidation and reduction), conjointly with field-driven ion diffusion, generate an oxide layer on the anode's surface [140]. The dimension of nano-topographies is easily controlled by changing the applied potential, electrical current power, anodization time, electrolyte composition, and temperature [141]. The formation of these anodized-produced nano-topographies have many advantages, including their promising potential in delivering many types of drugs [142], such as bioactive molecules [143], and growth factors [144] to enhance the cellular response, affecting the contact surface area and leading to enhanced wettability, inducing mechano-bactericidal effects [145], improving implant to bone bonding, etc. 


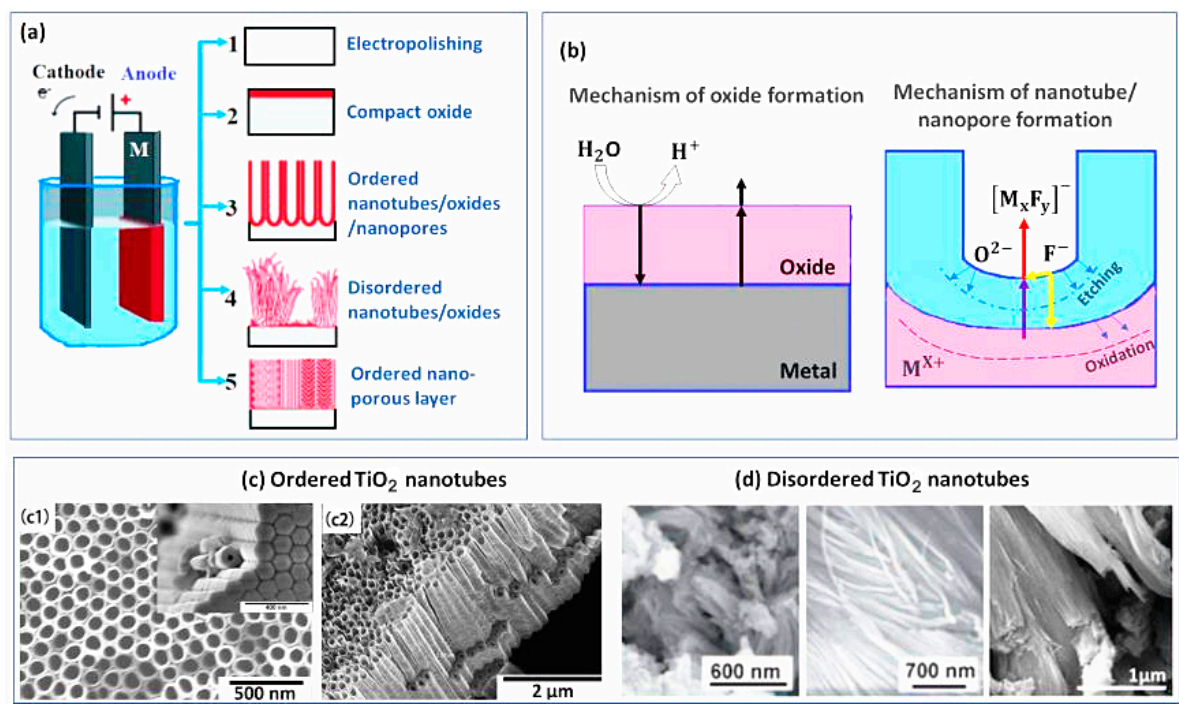

Figure 13. (a) The fabrication of various topographies on metallic substrates by the anodization method; (b) the mechanism of oxide, nanotube, and nanopore formation by anodization; (c1) and (c2) ordered $\mathrm{TiO}_{2}$ nanotubes [146]; (d) disordered $\mathrm{TiO}_{2}$ nanotubes [147] (reproduced with permission number: 5071091497388, Elsevier).

Together with the type of fabricated nanostructure by anodization, their dimension is important. The nanotube length can influence biocompatibility and its diameter can affect cell adhesion and proliferation [148,149]. Many studies have shown that favorable osteoconductive responses experimented on in the range of 30-120 nm can be achieved in a $\sim 70 \mathrm{~nm}$ diameter, and optimal differentiation and proliferation can be achieved in $\sim 80 \mathrm{~nm}$ [129]. Su et al. [149] claimed that in vitro and in vivo experiments prove the positive effect of $\mathrm{TiO}_{2}$ nanotube formation on osseointegration, osteogenic activity, cell differentiation, proliferation, mineralization, and anti-microbial properties. Besides, this electrochemical-based surface treatment can be performed on pre-treated macro and microporous Ti implant surfaces, fabricating favorable textures for nanoscale cellular interactions [149]. In addition, mechanical pull-out and histological tests in rabbit models indicate that about nine-fold improved bone-bonding was achieved in $\mathrm{TiO}_{2}$ nanotube-modified Ti surfaces [149]. Lee et al. [150] produced $\mathrm{TiO}_{2}$ nanotube arrays through a two-step anodic oxidation procedure on Ti dental implants in a solution containing ethylene glycol with $0.5 \mathrm{wt}$ \% NH4F. The in vivo studies on rabbit models show further improved osseointegration results compared to machined, sandblasted, large-grit and acid-etched surfaces; these nanotubes can also be used as reservoirs for recombinant human bone morphogenetic protein-2 (rhBMP-2). $\mathrm{Hu}$ et al. [151] indicated far better interfacial adhesion and osseointegration in anodicproduced $\mathrm{TiO}_{2}$ nanotubes on ultra-fine-grained titanium; a grain refinement strategy of high-pressure torsion processing was used in order to enhance the weak bonding of anodic $\mathrm{TiO}_{2}$ nanotubes to the substrate.

\subsubsection{Plasma Spraying}

Plasma spraying is known as a reliable nano-scale coating technique that can also be used to roughen a surface. Figure 14 shows the schematic of this process including an electrical power source, water-based cooling system, gas flow control, powder injector, cathode, anode, and insulators, along with the affected variables [23]. In this method, a direct current arc plasma gun is utilized to spray the melted powder material onto the $\mathrm{Ti}$ substrate; it can also roughen and increase the surface area of the implant material [152]. It was reported that the plasma spraying technique can facilitate and accelerate the formation of a bone-to-implant interface [153]. 


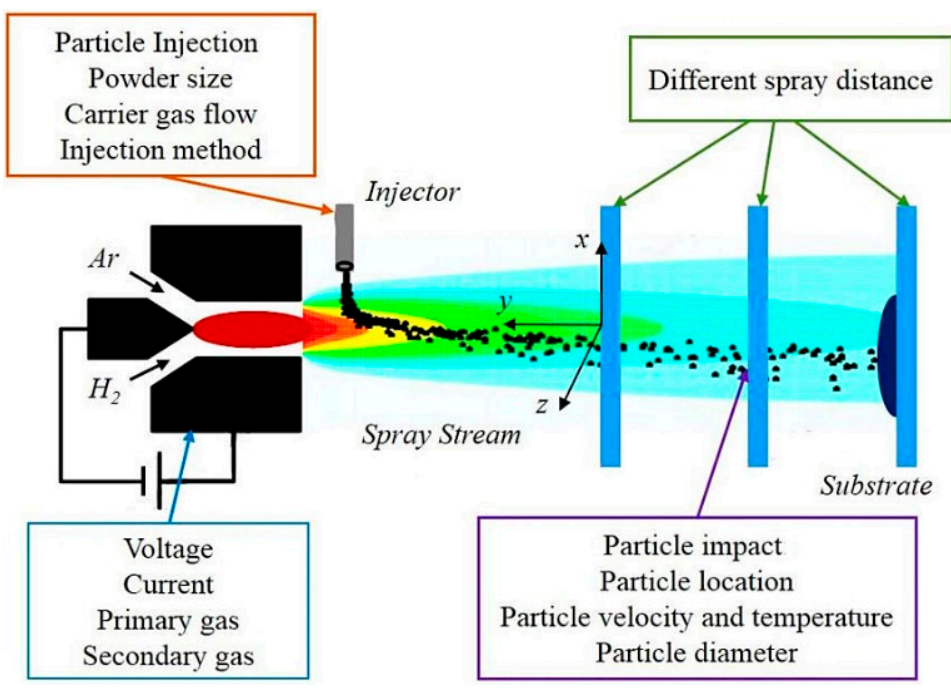

Figure 14. A schematic of a plasma spraying technique along with the affecting factors [23] (reproduced with permission number: 5071091227684, Elsevier).

Until now, numerous studies have been focused on plasma sprayed coatings on $\mathrm{Ti}$ implant surfaces, showing their great potential to improve the properties and functionality of Ti implants; meanwhile, hydroxyapatite (HA) and calcium phosphate coatings are of special interest for enhancing the bioactivity of these surfaces [154-156]. Coating of composite materials can also be achieved by the utilization of plasma spraying, Li et al. [157] prepared a nano- $\mathrm{TiO}_{2} / \mathrm{Ag}$ coating to enhance bioactivity and bactericidal properties. Functionally graded (HA)/ Ti-6Al-4V composite coatings were produced by plasma spraying. This three-layered structure, without any distinct interfaces among layers, had improved and graded mechanical properties comparable to the natural bone, with enhanced tensile adhesion strength and toughness [158]. Additionally, a biomimetic nano-porous composite $\left(50 \mathrm{HA}-50 \mathrm{TiO}_{2}\right)$ was produced by plasma spraying for orthopedic applications on Ti6Al4V alloy, showing the natural bone-like nano-porous morphology favorable for effective bone bonding with an implant's surface [159]. Hameed et al. [160] used axial suspension plasma spraying (SPS) and atmospheric plasma spraying (APS) procedures to induce HA coating and tailor a Ti6Al4V surface for orthopedic implant applications. In this study, various coatings using different processing variables were produced, including two HA coatings by APS (P1 and P2) and four coatings with SPS HA (S1, S2, S3, and S4). The results indicated the optimal properties of S3 (1.3 times increased adhesion strength and 9.5 times higher corrosion resistance compared to P1). After S3, the best results confirmed in the P1 sample, both of these samples have favorable biocompatibility [160]. Figure 15 shows a brief illustration of the research. For the preparation of the $\mathrm{S} 3$ sample, the following parameters were used: $150(\mathrm{~L} / \mathrm{min})$ gas flow rate, $6.10(\mathrm{~kJ} / \mathrm{mol})$ enthalpy, $220 \mathrm{~A}$ arc current, $70 \mathrm{~mm}$ stand-off distance, and $36 \mu \mathrm{m}$ coating thickness [160]. Briefly, the SPS method indicated better hMSCs cell viability and corrosion performance. 


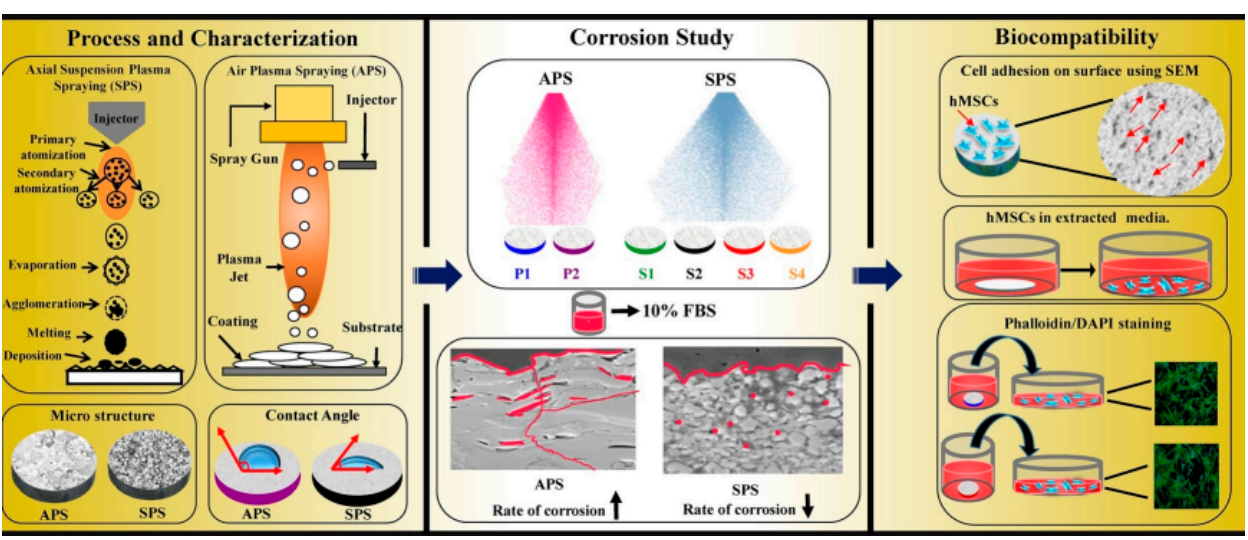

Figure 15. A schematic of SPS and APS methods, leading to different microstructures and wettability; corrosion studies in $10 \%$ fetal bovine serum (FBS) with $0.1 \%$ sodium azide, and in vitro biocompatibility experiments by hMSCs [160] (reproduced with permission number: 5071090717980 , Elsevier).

\subsubsection{Pulsed Laser Deposition}

The pulsed laser deposition (PLD) technique is one of the physical vapor deposition (PVD) derivatives in which a high-power laser beam with a narrow frequency bandwidth is utilized to vaporize the substrate. PLD techniques are generally used to produce a variety of nanotubes, nanopores, nano-powders, and quantum dots. The most advantageous aspect of PLD is that it can be applied to almost any target material [161,162]. In addition, PLD has the potential to further tailor nanostructure morphology by changing the process parameters such as wavelength, laser energy, gas pressure, etc. Many in vitro and in vivo investigations show the beneficial aspects of PLD utilization in the production of ceramic, titania, calcium phosphate-based, and silicon oxide coatings for biomedical applications [163,164], indicating the superior osseointegration properties of CaP functionalized metallic implants via the PLD technique. PLD techniques can produce HA coatings (as a popular surface strategy for Ti implants), including doped species. [165]. Overall, PLD is one of the most favorable techniques for fabricating bioactive coatings on metallic implants. PLD can promote implant cytocompatibility [166], corrosion resistance [167], antibacterial effect [168], drug-eluting characteristics [169], osteogenesis [170], and mechanical properties [171]. Even some organic animal-based material can be used in the PLD method; for example, Duta et al. [172] produced the ovine and bovine-derived hydroxyapatite thin films on a Ti substrate with a rougher and more adhesive nature. Despite the numerous benefits of PLD, it also has some limitations and shortcomings. PLD may lead to compositional changes and irreversible destruction of chemical bonds and initial material structures. This issue usually occurs in complex and delicate biomolecules, drugs, and biopolymers. Finally, these compositional changes and destructions affect the quality of the deposited film [173].

\section{Multifunctional Biomimetic Surfaces and Their Applications}

Nature as the best teacher has numerous examples of multifunctional hierarchical micro/nanostructures. These natural structures are generated to actively adapt to extremely harsh environmental conditions. They also provide other required properties such as selfcleaning, bactericidal effects, and even fabricating fascinating colors to attract the attention of possible mates; some of these examples can be found in studies by Vijayan et al. [174] and Hu et al. [175]. In this regard, tailoring a multifunctional biomimetic surface on Ti material, as one of the most used materials in biomedical applications, is of high importance, and has attracted much attention from academic society, with a sharp increase in the number of studies conducted in this area; most of these studies on Ti focused on the fabrication of bioactive, bactericidal, and drug loading structures. Figure 16 lists the strategies for achieving bioactive and antibacterial properties on Ti surfaces through various types of surface modification [176]. 
STRATEGIESFOR BIOACTIVE \& ANTIBACTERIALSURFACES

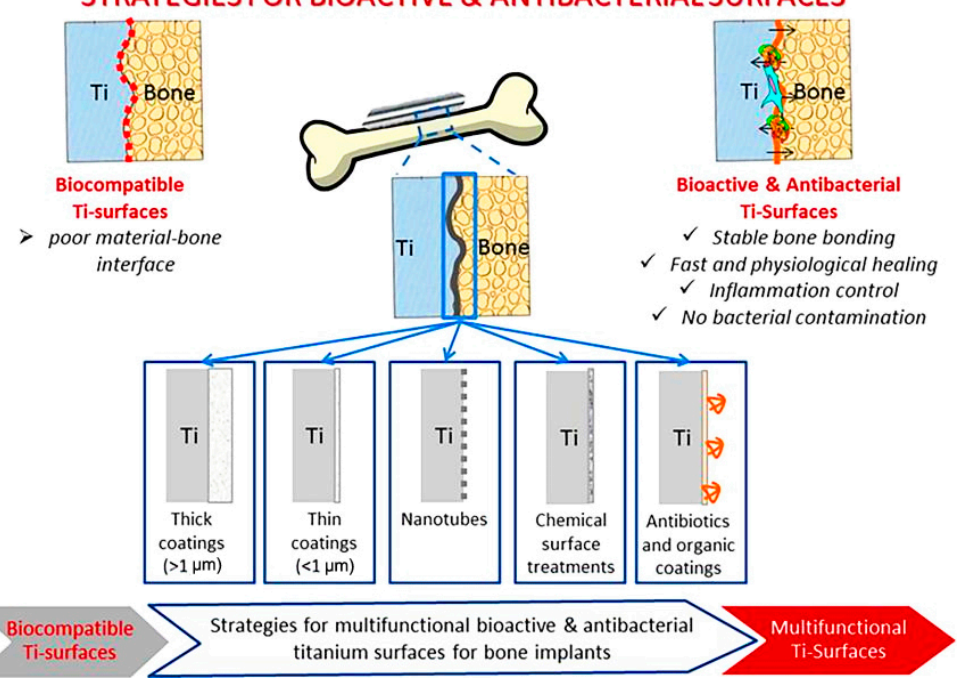

Figure 16. The strategies for achieving bioactive and antibacterial properties on Ti surfaces through various types of surface modifications [176] (reproduced with permission number: 5071090149493, Elsevier).

Spriano et al. [177] produced two types of multifunctional Ti surface. The first one, with an inorganic modification aiming to induce in vivo apatite precipitation with complex micro/nano-roughness and modified chemistry (full of hydroxyls groups), showed enhanced wettability and protein adsorption. The second surface was additionally processed with alkaline phosphatase (ALP) grafting. The results showed increased cell proliferation rates and higher osteoblast differentiation, with more filopodia in these nanotextures compared to traditional polished and grit blasted samples [177]. Biomimetic growth of nanostructured $\mathrm{TiO}_{2}$ can be performed through plasma treatment. Liu et al. [178] reported the fabrication of bioactive nanostructured $\mathrm{TiO}_{2}$ surfaces with grain sizes less than $50 \mathrm{~nm}$ using plasma spraying following hydrogen plasma immersion ion implantation (PIII), leading to bone-like apatite generation. It was seen that a hydrogenated surface increases the negatively charged functional groups, and a refined microstructure improves the surface adsorption, leading to the facilitation of apatite formation and bioactivity [178]. One of the well-known methods for the loading and releasing of various drugs, as well as anti-inflammation and antibacterial compounds, in Ti implants is the production of $\mathrm{TiO}_{2}$ nanotubes through electrochemical methods, which could be beneficial in orthopedic implants [179]. A coating strategy can also be used to functionalize the Ti surface by the utilization of antimicrobial peptides and amphiphilic oligopeptides. These peptides show multifunctional behaviors including a reduction in pro-inflammatory cytokines, along with the increment of anti-inflammatory cytokines, down-regulation of macrophage activation, prevention of the adhesion of bacteria, and increases in osteoblast viability [180-182]. Achieving simultaneous bioactive and antibacterial surfaces on Ti can be achieved by the utilization of either inorganic (metallic ions, nanoparticles, and their oxides, e.g., $\mathrm{Ag}, \mathrm{Cu}$, $\mathrm{Zn}$, and $\mathrm{Ce}$ ) or organic (antibiotics) antibacterial agents. It seems that the inorganic scheme is better than the organic ones due to its capability to respond to polymicrobial infections without having an issue with resistant bacterial strains, which is among the main issues in antibiotics $[176,183]$. In addition to the so-called studies, Table 1 briefly introduces some of the investigations about multifunctional Ti material production using various techniques, some of which are not categorized in surface modification techniques. The advantages of biomimetic multifunctional tailoring of Ti surfaces are vast and, because of that, make it a crucial research topic with the potential to revolutionize biomedical engineering. As such, the future of this field is dependent on developing new methods and improving the current ones. This paper provides a brief review about these methods and aims to incite future investigations. 
Table 1. The multifunctional properties in Ti and Ti6Al4V alloy, techniques, and surface types.

\begin{tabular}{|c|c|c|c|c|}
\hline Substrate & Technique & Surface Type or Coating & Multifunctional Properties & Ref. \\
\hline C.P. Ti & $\begin{array}{l}\text { Layer-by-layer } \\
\text { self-assembly }\end{array}$ & $\begin{array}{c}\text { Phospholipid-based } \\
\text { multifunctional coating with } \\
\text { phospholipids-based polymers, } \\
\text { type I collagen (Col-I), and } \\
\text { Arg-Glu-Asp-Val (REDV) peptide }\end{array}$ & $\begin{array}{l}\text { Inhibit platelet adhesion, smooth } \\
\text { muscle cells, and endothelial cells } \\
\text { proliferation }\end{array}$ & [184] \\
\hline C.P. Ti & $\begin{array}{l}\text { Plasma electrolytic } \\
\text { processing }(\mathrm{PEP})\end{array}$ & $\begin{array}{c}\mathrm{Ag} \text { substituted } \\
\text { hydroxyapatite } / \mathrm{TiO}_{2} \text { composite }\end{array}$ & $\begin{array}{l}\text { Corrosion-resistant, bioactive, } \\
\text { antibacterial }\end{array}$ & [185] \\
\hline C.P. Ti & Electrodeposition & $\begin{array}{l}\text { Cu-substituted carbonated } \\
\text { hydroxyapatite coating }\end{array}$ & $\begin{array}{l}\text { Antibacterial function against } \\
\text { Escherichia coli, corrosion-resistant, } \\
\text { favorable osteoblast function }\end{array}$ & [60] \\
\hline C.P. Ti & $\begin{array}{l}\text { Aqueous precipitation } \\
\text { (electrochemical) }\end{array}$ & $\begin{array}{c}\text { Ag-doped } \beta-\mathrm{Ca}_{3}\left(\mathrm{PO}_{4}\right)_{2} / \text { chitosan } \\
\text { hybrid composite coatings }\end{array}$ & $\begin{array}{l}\text { Antibacterial, biocompatible, } \\
\text { corrosion-resistant }\end{array}$ & [186] \\
\hline C.P. Ti & Micro arc oxidation & $\begin{array}{l}\text { Zn-incorporated } \mathrm{TiO}_{2} \text { porous } \\
\text { coating }\end{array}$ & Antibacterial, corrosion resistant & [187] \\
\hline C.P. Ti & Micro arc oxidation & $\begin{array}{c}\mathrm{Cu} \text { NP-incorporated } \\
\text { coating }\end{array}$ & $\begin{array}{l}\text { Antibacterial activity against } \\
\text { Staphylococcus aureus, the } \\
\text { enhanced cellular activity of } \\
\text { osteoblasts and endothelial cells }\end{array}$ & [188] \\
\hline C.P. Ti & $\begin{array}{l}\text { Micro arc oxidation }+ \\
\text { dopamine dip coating }+ \\
\mathrm{AgNO}_{3} \text { reduction }\end{array}$ & $\begin{array}{c}\text { Hierarchical coating by Ag NP } \\
\text { deposition on micro-nano-porous } \\
\mathrm{TiO}_{2}\end{array}$ & $\begin{array}{l}\text { Anticorrosion, antibacterial } \\
\text { properties against Staphylococcus } \\
\text { aureus, optimal osteoblast cell } \\
\text { function }\end{array}$ & [189] \\
\hline C.P. Ti & $\begin{array}{l}\text { Plasma electrolytic } \\
\text { oxidation }\end{array}$ & $\begin{array}{l}\mathrm{TiO}_{2}+\mathrm{ZnO} \mathrm{NP} \text { in } \\
\text { phosphate-based electrolyte }\end{array}$ & $\begin{array}{c}\text { Anticorrosion, antibacterial effect } \\
\text { against both Gram-positive and } \\
\text { Gram-negative bacteria }\end{array}$ & [190] \\
\hline C.P. Ti & Electrostatic spraying & $\begin{array}{l}\text { Ag-incorporated hydroxyapatite } \\
\text { coating }\end{array}$ & $\begin{array}{c}\text { Antibacterial activity against } \\
\text { Escherichia coli, optimal osteoblast } \\
\text { cell function }\end{array}$ & [191] \\
\hline C.P. Ti & $\begin{array}{l}\text { Anodic oxidation }\left(\mathrm{TiO}_{2}\right) \\
\text { and electrodeposition } \\
\text { (Ca-P) }\end{array}$ & $\begin{array}{c}\mathrm{TiO}_{2}+\text { calcium } \\
\text { Phosphate, }(\mathrm{Ca}-\mathrm{P}) \text { coating }\end{array}$ & $\begin{array}{c}\text { Antibacterial function against } \\
\text { Staphylococcus aureus, anticorrosion }\end{array}$ & [192] \\
\hline C.P. Ti & $\begin{array}{l}\text { Anodic oxidation and } \\
\text { electrodeposition }\end{array}$ & $\begin{array}{l}\text { Ag-Mn-doped double-layer } \\
\text { hydroxyapatite coating }\end{array}$ & $\begin{array}{c}\text { Super-hydrophilic, } \\
\text { corrosion-resistant, improved } \\
\text { osteoblast cell function }\end{array}$ & [193] \\
\hline C.P. Ti & $\begin{array}{l}\text { Electrochemical and heat } \\
\text { treatment }\end{array}$ & $\begin{array}{l}\text { Ag-hydroxyapatite composite } \\
\text { coatings }\end{array}$ & $\begin{array}{l}\text { Antibacterial function against } \\
\text { Escherichia coli }\end{array}$ & [194] \\
\hline C.P. Ti & Hydrothermal method & $\begin{array}{c}\text { Ag- and Sr-substituted } \\
\text { hydroxyapatite coating on } \\
\text { dopamine functionalized titanium }\end{array}$ & $\begin{array}{c}\text { Antibacterial function against } \\
\text { Escherichia coli and Staphylococcus } \\
\text { aureus, reduction of Ag } \\
\text { cytotoxicity }\end{array}$ & [195] \\
\hline Ti6Al4V & Micro arc oxidation & $\begin{array}{l}\text { Multi-layer } \mathrm{HA} / \mathrm{TiO}_{2} \text { coatings } \\
\text { containing } \mathrm{Ag}\end{array}$ & $\begin{array}{c}\text { Enhancement of bioactivity, } \\
\text { antibacterial effect }\end{array}$ & [196] \\
\hline Ti6Al4V & $\begin{array}{l}\text { Hybrid approach of } \\
\text { magnetron sputtering } \\
\text { and micro-arc oxidation }\end{array}$ & $\begin{array}{l}\text { Zn-doped } \mathrm{ZrO}_{2} / \mathrm{TiO}_{2} \text { porous } \\
\text { coatings }\end{array}$ & $\begin{array}{c}\text { Antibacterial property against } \\
\text { Staphylococcus aureus, } \\
\text { corrosion-resistant, } \\
\text { cytocompatibility }\end{array}$ & [197] \\
\hline Ti6Al4V & Electrodeposition & $\begin{array}{l}\text { Zn-halloysite nanotubes } / \mathrm{Sr}^{2+} \text {, } \\
\qquad \mathrm{Sm}^{2+} \text { substituted } \\
\text { hydroxyapatite bilayer coating }\end{array}$ & $\begin{array}{l}\text { Corrosion-resistant, bioactive, } \\
\text { favorable antibacterial function }\end{array}$ & [198] \\
\hline
\end{tabular}




\section{Forthcoming Modern Implants}

The development process in medical applications is extremely fast, especially in relation to medical implants due to the growing number of the world's aging population. In this regard, many modern materials, procedures, and technologies have been proposed and studied. In addition, in the case of implant surface technologies, new concepts have been introduced which cannot be categorized in traditional classifications. This section aims to present and discuss these modern technologies; some of them have not yet been studied directly on titanium, but they may inspire future studies and pave the way for new advances in the field.

Modern hydrophobic surfaces are highly interested in the dental and ophthalmological communities. Hydrophobic surfaces can prevent dental enamel erosion [199] and have many applications in the production of eye lenses [200]. A superhydrophobic surface can be produced by various methods and shows promising properties. Ma et al. [201] produced a fluorine-based superhydrophobic surface via electrochemical etching with anticorrosion and anti-abrasion characteristics. Additionally, Bains et al. [202] fabricated a hierarchical hydrophobic surface with long-term antibacterial properties, minimizing wetting through biological secretions and inhibiting corrosion. They developed this kind of superhydrophobicity by the production of benzimidazolium ionic liquids ILs-1(a-d)-based metal hybrid nanocomposites by the utilization of different metals, such as silver, gold, and copper. In addition, self-healing hydrophobic coatings with high transparency, excellent stability, and favorable adhesion were introduced [203], which can be further improved for use in the implant industry. A study by Tang et al. [204] proved the effectiveness of $\mathrm{TiO}_{2}$ nanotube-based superhydrophobic surfaces, with more than $150^{\circ}$ contact angle in the prevention of bacterial contamination. The superhydrophobic surfaces of Ti show considerable self-cleaning, prevention of bacterial adhesion, and enhanced anticoagulant characteristics; these surfaces can be produced by various methods such as laser ablation, electrochemical processes, high-speed micro-milling, electrodeposition, anodic oxidation, and fluoroalkylsilane modifications [205]. Recently, new approaches in bone regeneration of implants have also been introduced and practiced. Digital and visualized guided bone regeneration (GBR) is among these new technologies, with promising benefits in precision and controllability of bone augmentation procedures [206]. Yin et al. [207] used a novel dental implant design to preserve the alveolar ridge height by mechanical memory in which, through 3D printing technology, a micron-sized pore-channel structure was fabricated, with a more bony ingrowth, thus assuring the required horizontal mechanical force and mimicking natural teeth force. In this design, the pore-channel considerably assists stem cell differentiation and tissue morphogenesis.

\subsection{Four-Dimensional (4D) Printing}

The production of shapeshifting materials using four-dimensional (4D) printing can be a revolutionary approach in biomedical applications. These $4 \mathrm{D}$ printed materials have the potential to reconfigure themselves upon demand when exposed to changes in temperature, electric current, stress, etc. The future of $4 \mathrm{D}$ printing can address complex medical issues and further improve and facilitate patient-specific designs. Through $4 \mathrm{D}$ printing technology, a 3D physical object can be fabricated by adding smart material layer by layer via computer-operated computer-aided design (CAD) data [208]. The smart material function adds the fourth dimension, with the capability to transform over time, in which the printed products become sensitive to parameters such as temperature, humidity, time, electricity, magnetism, etc. [209]. The main applications for 4D printing in medicine were reported in dentistry [210], prosthetics [211], and implants [212]. In addition, 4D printing technology can be used in drug delivery systems, scaffolds [213], and stents [214]. The $4 \mathrm{D}$ printed drug delivery systems can be stimulated by external parameters to release drugs, and 4D-printed containers [215,216] are popular examples, with the other example being expandable gastroretentive devices [217]. 


\subsection{Metasurfaces and Metamaterials}

Metamaterials are modern artificial composite structures with exceptional material properties and applications displaying exotic physical properties that surpass or complement the usual properties seen in nature. Metamaterial, as a new frontier in science and technology, is a multi-disciplinary field involving physics, material science, engineering, and chemistry. Metamaterials (MM) as synthetic composite structures use a conventional type of material such as metals and plastics, but they act entirely differently to bulk materials, presenting exotic and exceptional properties. Metamaterials' structures are composed of microscopic patterns that can interact with light, electromagnetic, elastic, acoustic, and thermal properties in unconventional ways.

Metasurfaces are thin-films which include individual elements that have been introduced to defeat the obstacles that metamaterials are confronted with. The unique benefits of metasurfaces and metamaterials can be utilized in biomedical applications. For instance, the stress shielding issue mostly seen in orthopedic bone implants can be solved by lattice and shell-type architecture in bone scaffolds, in which the varied topology of nodal connections has great potential to control the relative rigidity of the metamaterial [218]. Three-dimensional printing technology, along with multi-objective genetic algorithm (GA) optimization with the finite element (FE) simulation, can be used to produce an optimum force-displacement response in designing printable tunable stiffness metamaterial for bone healing [219]. Mechanical 3D metamaterial with a porous structure is among the best materials for bone implants, with a graded Poisson's ratio distribution to optimize stress and micromotion distributions. In this regard, Ghavidelnia et al. [220] analytically designed an auxetic 3D re-entrant structure with tailored elastic modulus and Poisson's ratio, and which has great potential to solve the stress shielding problem. Kolken et al. [221] produced a novel meta-implant by 3D printing technology. Their designed non-auxetic meta-biomaterials with a deformable porous outer layer were intended to be used in acetabular revision surgeries. During implantation, the outer layer plastically deforms into the defects, enhancing the initial stability and stimulating the surrounding bone ingrowth. This space-filling behavior with 3D printed lattice (including six-unit cell) is highly beneficial for improving the mechanical performance of implants and enhancing bone-mimicking characteristics. Figure 17 shows this space-filling meta-implant.

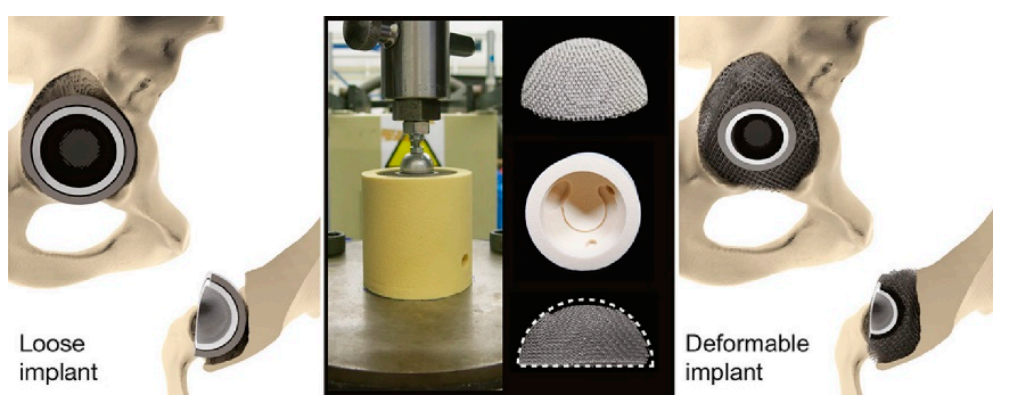

Figure 17. The meta-implant design has the potential to deform and fill up defects, restoring the physiological loading condition. The implants were compressed in bone-mimicking molds to evaluate their deformability [221].

\section{Conclusions}

In recent years, titanium implant modification methods have shifted from improving mechanical strength and reducing yield strength toward multifunctional designs. Multifunctional surface designs can improve biocompatibility and osseointegration. They can also lead to an optimal cellular response, wettability, roughness, and even drug loading and antibacterial properties. In order to achieve all these crucial requirements in biomedical applications, developing modern and optimum techniques is vital. Besides, the existing methods must be improved and modified accordingly. Recent investigations in strength, roughness, and wettability issues have shifted toward hierarchical structures, mimicking 
the periphery tissue (specifically bone, in the case of titanium), along with activating the surface with organic, inorganic, and biochemical materials. Many techniques based on mechanical, physical, chemical, and biochemical methods were introduced and explained in the literature. Besides, the combination of these methods is highly interesting for the community, since each of them has its advantages and disadvantages. Three-dimensional printing technology emerged in the last decade and, despite its infancy, has opened new horizons for developing modern implants with patient-specific properties. Based on the literature review, it seems that the importance of micro/nano-gradation in the surface modification of Ti and its alloys, along with providing multifunctional properties, is more than the utilized technique; hence, in this paper, special attention was paid to tailoring micro/nano-grade surface structures, which is well suited to cellular and biosystems' dimensions and can actively mimic their functions. In this regard, firstly, basic requirements such as roughness, wettability, biocompatibility, osteogenesis, and bactericidal properties were discussed. Then, macro-, micro-, and nano-grade surface modification techniques were thoroughly explained, including acid-etching, sandblasting, 3D printing, and laser surface texturing in the macro-grade group, SLA techniques in the micro-grade group, and electrochemical surface treatment, plasma spraying, and PLD in the nano-grade group. Subsequently, the multifunctional biomimetic surfaces were discussed. Finally, the forthcoming modern implants, with attention paid to $4 \mathrm{D}$ printing and novel metasurfaces and metamaterials, were explained. It seems that these revolutionary techniques have a very promising future in the medical implant industry. Overall, it was suggested that improving the exciting traditional techniques, further modifying novel methods such as metasurfaces, or designing new ones by combining the so-called methods, along with developing modern procedures, will be highly beneficial. By collecting the required information from the literature, encompassing both traditional and modern procedures, this review paper can pave the way toward tailoring modern and more efficient processes in the surface treatment of Ti and its alloys.

Author Contributions: J.L. and P.Z. designed this study. P.Z. and H.S. analyzed the data and helped in data collection. S.A. and J.L. participated in its design and wrote the paper. All authors have read and agreed to the published version of the manuscript.

Funding: This work was supported by Youth Innovation Team of Shaanxi Universities of Education Department of Shaanxi Provincial Government (Grant No. 2019-73), Education Department of Shaanxi Provincial Government (Grant No. 20JK0700), Shaanxi Key Research and Development Program of Shaanxi Science and Technology Department (Grant No. 2020GY-316).

Institutional Review Board Statement: Not applicable.

Informed Consent Statement: Not applicable.

Data Availability Statement: The data presented in this study are available in references.

Conflicts of Interest: The authors declare no conflict of interest.

\section{References}

1. Elias, C.N.; Lima, J.H.C.; Valiev, R.; Meyers, M.A. Biomedical applications of titanium and its alloys. JOM 2008, 60, 46-49. [CrossRef]

2. Niinomi, M.; Boehlert, C.J. Titanium Alloys for Biomedical Applications. In Advances in Metallic Biomaterials; Springer: Berlin/Heidelberg, Germany, 2015; pp. 179-213, ISBN 978-3-662-46836-4.

3. Chen, L.-Y.; Cui, Y.-W.; Zhang, L.-C. Recent development in beta titanium alloys for biomedical applications. Metals 2020, 10, 1139. [CrossRef]

4. Niinomi, M.; Liu, Y.; Nakai, M.; Liu, H.; Li, H. Biomedical titanium alloys with Young's moduli close to that of cortical bone. Regen. Biomater. 2016, 3, 173-185. [CrossRef] [PubMed]

5. Gode, C.; Attarilar, S.; Eghbali, B.; Ebrahimi, M. Electrochemical behavior of equal channel angular pressed titanium for biomedical application. AIP Conf. Proc. 2015, 1653, 20041. [CrossRef]

6. Wang, L.; Lu, W.; Qin, J.; Zhang, F.; Zhang, D. Effect of precipitation phase on microstructure and superelasticity of cold-rolled beta titanium alloy during heat treatment. Mater. Des. 2009, 30, 3873-3878. [CrossRef] 
7. Wang, L.; Xie, L.; Lv, Y.; Zhang, L.; Chen, L.; Meng, Q.; Qu, J.; Zhang, D.; Lu, W. Microstructure evolution and superelastic behavior in Ti-35Nb-2Ta-3Zr alloy processed by friction stir processing. Acta Mater. 2017, 131, 499-510. [CrossRef]

8. Zhang, L.; Chen, L. A review on biomedical titanium alloys: Recent progress and prospect. Adv. Eng. Mater. 2019, $21,1801215$. [CrossRef]

9. Wang, L.; Xie, L.; Zhang, L.; Chen, L.; Ding, Z.; Lv, Y.; Zhang, W.; Lu, W.; Zhang, D. Microstructure evolution and superelasticity of layer-like $\mathrm{NiTiNb}$ porous metal prepared by eutectic reaction. Acta Mater. 2018, 143, 214-226. [CrossRef]

10. Wang, L.; Wang, C.; Lu, W.; Zhang, D. Superelasticity of NiTi-Nb metallurgical bonding via nanoindentation observation. Mater. Lett. 2015, 161, 255-258. [CrossRef]

11. Attarilar, S.; Yang, J.; Ebrahimi, M.; Wang, Q.; Liu, J.; Tang, Y.; Yang, J. The toxicity phenomenon and the related occurrence in metal and metal oxide nanoparticles: A brief review from the biomedical perspective. Front. Bioeng. Biotechnol. $2020,8,822$. [CrossRef]

12. Liu, X.; Chu, P.K.; Ding, C. Surface modification of titanium, titanium alloys, and related materials for biomedical applications. Mater. Sci. Eng. R Rep. 2004, 47, 49-121. [CrossRef]

13. Kirby, R.; Heard, S.; Miller, P.; Eardley, I.; Holmes, S.; Vale, J.; Bryan, J.; Liu, S. Use of the ASI titanium stent in the management of bladder outflow obstruction due to benign prostatic hyperplasia. J. Urol. 1992, 148, 1195-1197. [CrossRef]

14. Khodaei, M.; Valanezhad, A.; Watanabe, I.; Yousefi, R. Surface and mechanical properties of modified porous titanium scaffold. Surf. Coat. Technol. 2017, 315, 61-66. [CrossRef]

15. Kang, H.-G.; Jeong, Y.-S.; Huh, Y.-H.; Park, C.-J.; Cho, L.-R. Impact of surface chemistry modifications on speed and strength of osseointegration. Int. J. Oral Maxillofac. Implants 2018, 33, 780-787. [CrossRef]

16. Huanhuan, J.; PengJie, H.; Sheng, X.; Binchen, W.; Li, S. The effect of strontium-loaded rough titanium surface on early osseointegration. J. Biomater. Appl. 2017, 32, 561-569. [CrossRef]

17. Ratner, B.D. A Perspective on Titanium Biocompatibility. In Titanium in Medicine; Springer: Berlin/Heidelberg, Germany, 2001; pp. 1-12.

18. Thomsen, P.; Larsson, C.; Ericson, L.E.; Sennerby, L.; Lausmaa, J.; Kasemo, B. Structure of the interface between rabbit cortical bone and implants of gold, zirconium and titanium. J. Mater. Sci. Mater. Electron. 1997, 8, 653-665. [CrossRef]

19. Rupp, F.; Liang, L.; Geis-Gerstorfer, J.; Scheideler, L.; Hüttig, F. Surface characteristics of dental implants: A review. Dent. Mater. 2018, 34, 40-57. [CrossRef] [PubMed]

20. Swain, S.; Rautray, T.R. Effect of Surface Roughness on Titanium Medical Implants. In Nanostructured Materials and Their Applications; Swain, B.P., Ed.; Springer: Singapore, 2021; pp. 55-80, ISBN 978-981-15-8307-0.

21. Bauer, S.; Park, J.; Faltenbacher, J.; Berger, S.; Von Der Mark, K.; Schmuki, P. Size selective behavior of mesenchymal stem cells on $\mathrm{ZrO}_{2}$ and $\mathrm{TiO}_{2}$ nanotube arrays. Integr. Biol. 2009, 1, 525-532. [CrossRef]

22. Park, J.; Bauer, S.; von der Mark, K.; Schmuki, P. Nanosize and vitality: $\mathrm{TiO}_{2}$ nanotube diameter directs cell fate. Nano Lett. 2007, 7, 1686-1691. [CrossRef] [PubMed]

23. Xue, T.; Attarilar, S.; Liu, S.; Liu, J.; Song, X.; Li, L.; Zhao, B.; Tang, Y. Surface modification techniques of titanium and its alloys to functionally optimize their biomedical properties: Thematic review. Front. Bioeng. Biotechnol. 2020, 8, 1-19. [CrossRef] [PubMed]

24. Prakash, C.; Kansal, H.K.; Pabla, B.; Puri, S.; Aggarwal, A. Electric discharge machining-A potential choice for surface modification of metallic implants for orthopedic applications: A review. Proc. Inst. Mech. Eng. Part B J. Eng. Manuf. 2016, 230, 331-353. [CrossRef]

25. Kim, Y.-W. Surface modification of Ti dental implants by grit-blasting and micro-arc oxidation. Mater. Manuf. Process. 2010, 25, 307-310. [CrossRef]

26. Brunette, D.M.; Tengvall, P.; Textor, M.; Thomsen, P. Titanium in Medicine: Material Science, Surface Science, Engineering, Biological Responses and Medical Applications; Springer: Berlin/Heidelberg, Germany; New York, NY, USA, 2001 ; ISBN 3540669361.

27. Wang, L.; Qu, J.; Chen, L.; Meng, Q.; Zhang, L.; Qin, J.; Zhang, D.; Lu, W. Investigation of deformation mechanisms in $\beta$-type Ti-35Nb-2Ta-3Zr alloy via FSP leading to surface strengthening. Met. Mater. Trans. A 2015, 46, 4813-4818. [CrossRef]

28. Xie, L.; Wang, L.; Jiang, C.; Lu, W. The variations of microstructures and hardness of titanium matrix composite (TiB+TiC)/Ti6Al-4V after shot peening. Surf. Coat. Technol. 2014, 244, 69-77. [CrossRef]

29. Guo, X.; Lu, W.; Wang, L.; Qin, J. A research on the creep properties of titanium matrix composites rolled with different deformation degrees. Mater. Des. 2014, 63, 50-55. [CrossRef]

30. Attarilar, S.; Salehi, M.-T.; Djavanroodi, F. Microhardness evolution of pure titanium deformed by equal channel angular extrusion. Met. Res. Technol. 2019, 116, 408. [CrossRef]

31. Attarilar, S.; Djavanroodi, F.; Irfan, O.; Al-Mufadi, F.; Ebrahimi, M.; Wang, Q. Strain uniformity footprint on mechanical performance and erosion-corrosion behavior of equal channel angular pressed pure titanium. Results Phys. 2020, $17,103141$. [CrossRef]

32. Zareidoost, A.; Yousefpour, M.; Ghaseme, B.; Amanzadeh, A. The relationship of surface roughness and cell response of chemical surface modification of titanium. J. Mater. Sci. Mater. Med. 2012, 23, 1479-1488. [CrossRef]

33. Wei, Q.; Wang, L.; Fu, Y.; Qin, J.; Lu, W.; Zhang, D. Influence of oxygen content on microstructure and mechanical properties of Ti-Nb-Ta-Zr alloy. Mater. Des. 2011, 32, 2934-2939. [CrossRef]

34. Li, J.; Wang, L.; Qin, J.; Chen, Y.; Lu, W.; Zhang, D. The effect of heat treatment on thermal stability of Ti matrix composite. J. Alloys Compd. 2011, 509, 52-56. [CrossRef] 
35. Rangel, A.L.R.; Falentin-daudré, C.; Natália, B.; Pimentel, S.; Eduardo, C.; Migonney, V.; Alves, A.P.R. Nanostructured titanium alloy surfaces for enhanced osteoblast response: A combination of morphology and chemistry. Surf. Coat. Technol. 2020, 383, 125226. [CrossRef]

36. Tian, L.; Tang, N.; Ngai, T.; Wu, C.; Ruan, Y.; Huang, L.; Qin, L. Hybrid fracture fixation systems developed for orthopaedic applications: A general review. J. Orthop. Transl. 2019, 16, 1-13. [CrossRef]

37. Wang, T.; Wan, Y.; Liu, Z. Effects of superimposed micro/nano-structured titanium alloy surface on cellular behaviors in vitro. Adv. Eng. Mater. 2016, 18, 1259-1266. [CrossRef]

38. Lai, M.; Cai, K.; Hu, Y.; Yang, X.; Liu, Q. Regulation of the behaviors of mesenchymal stem cells by surface nanostructured titanium. Colloids Surf. B Biointerfaces 2012, 97, 211-220. [CrossRef]

39. Moon, S.-K.; Kwon, J.-S.; Uhm, S.-H.; Lee, E.-J.; Gu, H.-J.; Eom, T.-G.; Kim, K.-N. Biological evaluation of micro-nano patterned implant formed by anodic oxidation. Curr. Appl. Phys. 2014, 14, S183-S187. [CrossRef]

40. Sirdeshmukh, N.; Dongre, G. Laser micro \& nano surface texturing for enhancing osseointegration and antimicrobial effect of biomaterials: A review. Mater. Today Proc. 2021, 44, 2348-2355. [CrossRef]

41. Ständert, V.; Borcherding, K.; Bormann, N.; Schmidmaier, G.; Grunwald, I.; Wildemann, B. Antibiotic-loaded amphora-shaped pores on a titanium implant surface enhance osteointegration and prevent infections. Bioact. Mater. 2021, 6, 2331-2345. [CrossRef] [PubMed]

42. Zhang, C.; Zhang, T.; Geng, T.; Wang, X.; Lin, K.; Wang, P. Dental implants loaded with bioactive agents promote osseointegration in osteoporosis: A review. Front. Bioeng. Biotechnol. 2021, 9. [CrossRef] [PubMed]

43. Tsimbouri, P.M.; Fisher, L.; Holloway, N.; Sjostrom, T.; Nobbs, A.H.; Meek, R.M.D.; Su, B.; Dalby, M.J. Osteogenic and bactericidal surfaces from hydrothermal titania nanowires on titanium substrates. Sci. Rep. 2016, 6, 36857. [CrossRef] [PubMed]

44. Cai, Y.; Bing, W.; Xu, X.; Zhang, Y.; Chen, Z.; Gu, Z. Topographical nanostructures for physical sterilization. Drug Deliv. Transl. Res. 2021, 1-14. [CrossRef]

45. López-Pavón, L.; Dagnino-Acosta, D.; López-Cuéllar, E.; Meléndez-Anzures, F.; Zárate-Triviño, D.; Barrón-González, M.; MorenoCortez, I.; Kim, H.Y.; Miyazaki, S. Synthesis of nanotubular oxide on Ti-24Zr-10Nb-2Sn as a drug-releasing system to prevent the growth of Staphylococcus aureus. Chem. Pap. 2021, 75, 2441-2450. [CrossRef]

46. Bonifacio, M.A.; Cerqueni, G.; Cometa, S.; Licini, C.; Sabbatini, L.; Mattioli-Belmonte, M.; De Giglio, E. Insights into arbutin effects on bone cells: Towards the development of antioxidant titanium implants. Antioxidants 2020, 9, 579. [CrossRef] [PubMed]

47. Ueno, T.; Ikeda, T.; Tsukimura, N.; Ishijima, M.; Minamikawa, H.; Sugita, Y.; Yamada, M.; Wakabayashi, N.; Ogawa, T. Novel antioxidant capability of titanium induced by UV light treatment. Biomaterials 2016, 108, 177-186. [CrossRef]

48. Ma, P.; Yu, Y.; Yie, K.H.R.; Fang, K.; Zhou, Z.; Pan, X.; Deng, Z.; Shen, X.; Liu, J. Effects of titanium with different micro/nano structures on the ability of osteoblasts to resist oxidative stress. Mater. Sci. Eng. C 2021, 123, 111969. [CrossRef] [PubMed]

49. Gittens, R.A.; McLachlan, T.; Olivares-Navarrete, R.; Cai, Y.; Berner, S.; Tannenbaum, R.; Schwartz, Z.; Sandhage, K.H.; Boyan, B.D. The effects of combined micron-/submicron-scale surface roughness and nanoscale features on cell proliferation and differentiation. Biomaterials 2011, 32, 3395-3403. [CrossRef] [PubMed]

50. Wang, Z.; Yan, Y.; Qiao, L. Protein adsorption on implant metals with various deformed surfaces. Colloids Surf. B Biointerfaces 2017, 156, 62-70. [CrossRef] [PubMed]

51. Guglielmotti, M.B.; Olmedo, D.G.; Cabrini, R.L. Research on implants and osseointegration. Periodontology 2000 2019, 79, 178-189. [CrossRef] [PubMed]

52. Grassi, S.; Piattelli, A.; De Figueiredo, L.C.; Feres, M.; De Melo, L.; Iezzi, G.; Alba, R.C., Jr.; Shibli, J.A. Histologic evaluation of early human bone response to different implant surfaces. J. Periodontol. 2006, 77, 1736-1743. [CrossRef]

53. Wennerberg, A.; Albrektsson, T.; Johansson, C.; Andersson, B. Experimental study of turned and grit-blasted screw-shaped implants with special emphasis on effects of blasting material and surface topography. Biomaterials 1996, 17, 15-22. [CrossRef]

54. Raines, A.L.; Olivares-Navarrete, R.; Wieland, M.; Cochran, D.L.; Schwartz, Z.; Boyan, B.D. Regulation of angiogenesis during osseointegration by titanium surface microstructure and energy. Biomaterials 2010, 31, 4909-4917. [CrossRef]

55. Cochran, D.L.; Schenk, R.K.; Lussi, A.; Higginbottom, F.L.; Buser, D. Bone response to unloaded and loaded titanium implants with a sandblasted and acid-etched surface: A histometric study in the canine mandible. J. Biomed. Mater. Res. 1998, 40, 1-11. [CrossRef]

56. Gittens, R.A.; Olivares-Navarrete, R.; Schwartz, Z.; Boyan, B.D. Implant osseointegration and the role of microroughness and nanostructures: Lessons for spine implants. Acta Biomater. 2014, 10, 3363-3371. [CrossRef] [PubMed]

57. Wennerberg, A.; Albrektsson, T. Implant surfaces beyond micron roughness. experimental and clinical knowledge of surface topography and surface chemistry. Int. Dent. SA 2004, 8, 14-18.

58. Mustafa, K.; Wroblewski, J.; Lopez, B.S.; Wennerberg, A.; Hultenby, K.; Arvidson, K. Determining optimal surface roughness of $\mathrm{TiO}_{2}$ blasted titanium implant material for attachment, proliferation and differentiation of cells derived from human mandibular alveolar bone. Clin. Oral Implants Res. 2001, 12, 515-525. [CrossRef] [PubMed]

59. Rønold, H.; Lyngstadaas, S.; Ellingsen, J. Analysing the optimal value for titanium implant roughness in bone attachment using a tensile test. Biomaterials 2003, 24, 4559-4564. [CrossRef]

60. Jemat, A.; Ghazali, M.J.; Razali, M.; Otsuka, Y. Surface modifications and their effects on titanium dental implants. BioMed Res. Int. 2015, 2015, 1-11. [CrossRef] [PubMed] 
61. Akkas, T.; Citak, C.; Sirkecioglu, A.; Güner, F.S. Which is more effective for protein adsorption: Surface roughness, surface wettability or swelling? Case study of polyurethane films prepared from castor oil and poly(ethylene glycol). Polym. Int. 2013, 62, 1202-1209. [CrossRef]

62. De Jonge, L.T.; Leeuwenburgh, S.; Wolke, J.G.C.; Jansen, J.A. Organic-inorganic surface modifications for titanium implant surfaces. Pharm. Res. 2008, 25, 2357-2369. [CrossRef]

63. Adabi, M.; Naghibzadeh, M.; Adabi, M.; Zarrinfard, M.A.; Esnaashari, S.S.; Seifalian, A.M.; Faridi-Majidi, R.; Aiyelabegan, H.T.; Ghanbari, H. Biocompatibility and nanostructured materials: Applications in nanomedicine. Artif. Cells Nanomed. Biotechnol. 2017, 45, 833-842. [CrossRef]

64. Cedervall, T.; Lynch, I.; Foy, M.; Berggård, T.; Donnelly, S.C.; Cagney, G.; Linse, S.; Dawson, K.A. Detailed identification of plasma proteins adsorbed on copolymer nanoparticles. Angew. Chem. Int. Ed. 2007, 46, 5754-5756. [CrossRef]

65. Vasak, C.; Busenlechner, D.; Schwarze, U.Y.; Leitner, H.F.; Guzon, F.M.; Hefti, T.; Schlottig, F.; Gruber, R. Early bone apposition to hydrophilic and hydrophobic titanium implant surfaces: A histologic and histomorphometric study in minipigs. Clin. Oral Implants Res. 2013, 25, 1378-1385. [CrossRef]

66. Berry, C.C.; Campbell, G.; Spadiccino, A.; Robertson, M.; Curtis, A.S. The influence of microscale topography on fibroblast attachment and motility. Biomaterials 2004, 25, 5781-5788. [CrossRef] [PubMed]

67. Mata, A.; Hsu, L.; Capito, R.; Aparicio, C.; Henrikson, K.; Stupp, S.I. Micropatterning of bioactive self-assembling gels. Soft Matter 2009, 5, 1228-1236. [CrossRef]

68. Dalby, M.J.; McCloy, D.; Robertson, M.; Wilkinson, C.D.; Oreffo, R.O. Osteoprogenitor response to defined topographies with nanoscale depths. Biomaterials 2006, 27, 1306-1315. [CrossRef] [PubMed]

69. Pérez-Garnes, M.; González-García, C.; Moratal, D.; Rico, P.; Salmerón-Sánchez, M. Fibronectin distribution on demixed nanoscale topographies. Int. J. Artif. Organs 2011, 34, 54-63. [CrossRef]

70. González-García, C.; Sousa, S.R.; Moratal, D.; Rico, P.; Salmerón-Sánchez, M. Effect of nanoscale topography on fibronectin adsorption, focal adhesion size and matrix organisation. Colloids Surf. B Biointerfaces 2010, 77, 181-190. [CrossRef] [PubMed]

71. Zhou, A.; Yu, H.; Liu, J.; Zheng, J.; Jia, Y.; Wu, B.; Xiang, L. Role of hippo-YAP signaling in osseointegration by regulating osteogenesis, angiogenesis, and osteoimmunology. Front. Cell Dev. Biol. 2020, 8, 8. [CrossRef]

72. Damiati, L.; Eales, M.G.; Nobbs, A.H.; Su, B.; Tsimbouri, P.M.; Salmeron-Sanchez, M.; Dalby, M.J. Impact of surface topography and coating on osteogenesis and bacterial attachment on titanium implants. J. Tissue Eng. 2018, 9. [CrossRef] [PubMed]

73. Le Guéhennec, L.; Soueidan, A.; Layrolle, P.; Amouriq, Y. Surface treatments of titanium dental implants for rapid osseointegration. Dent. Mater. 2007, 23, 844-854. [CrossRef]

74. Lossdorfer, S.; Schwartz, Z.; Wang, L.; Lohmann, C.; Turner, J.D.; Wieland, M.; Cochran, D.L.; Boyan, B.D. Microrough implant surface topographies increase osteogenesis by reducing osteoclast formation and activity. J. Biomed. Mater. Res. Part A 2004, 70, 361-369. [CrossRef]

75. Huo, S.-C.; Yue, B. Approaches to promoting bone marrow mesenchymal stem cell osteogenesis on orthopedic implant surface. World J. Stem Cells 2020, 12, 545-561. [CrossRef]

76. Gulati, K.; Maher, S.; Findlay, D.M.; Losic, D. Titania nanotubes for orchestrating osteogenesis at the bone-implant interface. Nanomedicine 2016, 11, 1847-1864. [CrossRef]

77. Shen, X.; Yu, Y.; Ma, P.; Luo, Z.; Hu, Y.; Li, M.; He, Y.; Zhang, Y.; Peng, Z.; Song, G.; et al. Titania nanotubes promote osteogenesis via mediating crosstalk between macrophages and MSCs under oxidative stress. Colloids Surf. B Biointerfaces 2019, 180, 39-48. [CrossRef]

78. Huang, J.; Zhang, X.; Yan, W.; Chen, Z.; Shuai, X.; Wang, A.; Wang, Y. Nanotubular topography enhances the bioactivity of titanium implants. Nanomed. Nanotechnol. Biol. Med. 2017, 13, 1913-1923. [CrossRef]

79. Broggini, N.; McManus, L.M.; Hermann, J.S.; Medina, R.U.; Schenk, R.K.; Buser, D.; Cochran, D.L. Peri-implant inflammation defined by the implant-abutment interface. J. Dent. Res. 2006, 85, 473-478. [CrossRef]

80. Teterycz, D.; Ferry, T.; Lew, D.; Stern, R.; Assal, M.; Hoffmeyer, P.; Bernard, L.; Uçkay, I. Outcome of orthopedic implant infections due to different staphylococci. Int. J. Infect. Dis. 2010, 14, e913-e918. [CrossRef]

81. Gomes, F.I.; Teixeira, P.; Oliveira, R. Mini-review: Staphylococcus epidermidisas the most frequent cause of nosocomial infections: Old and new fighting strategies. Biofouling 2014, 30, 131-141. [CrossRef] [PubMed]

82. Uppu, D.S.S.M.; Konai, M.M.; Sarkar, P.; Samaddar, S.; Fensterseifer, I.C.M.; Farias-Junior, C.; Krishnamoorthy, P.; Shome, B.R.; Franco, O.L.; Haldar, J. Membrane-active macromolecules kill antibiotic-tolerant bacteria and potentiate antibiotics towards Gram-negative bacteria. PLoS ONE 2017, 12, e0183263. [CrossRef] [PubMed]

83. Lakshmipraba, J.; Prabhu, R.N.; Sivasankar, V. Polymer Macromolecules to Polymeric Nanostructures: Efficient Antibacterial Candidates. In Nanostructures for Antimicrobial and Antibiofilm Applications; Springer: Cham, Switzerland, 2020; pp. $209-232$. [CrossRef]

84. Li, S.; Dong, S.; Xu, W.; Tu, S.; Yan, L.; Zhao, C.; Ding, J.; Chen, X. Antibacterial hydrogels. Adv. Sci. 2018, 5, 1700527. [CrossRef] [PubMed]

85. Vimbela, G.V.; Ngo, S.M.; Fraze, C.; Yang, L.; Stout, D.A. Antibacterial properties and toxicity from metallic nanomaterials. Int. J. Nanomed. 2017, 12, 3941-3965. [CrossRef] 
86. Gupta, N.; Santhiya, D.; Murugavel, S.; Kumar, A.; Aditya, A.; Ganguli, M.; Gupta, S. Effects of transition metal ion dopants (Ag, $\mathrm{Cu}$ and $\mathrm{Fe}$ ) on the structural, mechanical and antibacterial properties of bioactive glass. Colloids Surf. A Physicochem. Eng. Asp. 2018, 538, 393-403. [CrossRef]

87. Goudouri, O.-M.; Kontonasaki, E.; Lohbauer, U.; Boccaccini, A.R. Antibacterial properties of metal and metalloid ions in chronic periodontitis and peri-implantitis therapy. Acta Biomater. 2014, 10, 3795-3810. [CrossRef] [PubMed]

88. Wennerberg, A.; Albrektsson, T. Effects of titanium surface topography on bone integration: A systematic review. Clin. Oral Implants Res. 2009, 20, 172-184. [CrossRef] [PubMed]

89. Szmukler-Moncler, S.; Testori, T.; Bernard, J.P. Etched implants: A comparative surface analysis of four implant systems. J. Biomed. Mater. Res. 2004, 69, 46-57. [CrossRef]

90. Li, D.; Ferguson, S.J.; Beutler, T.; Cochran, D.L.; Sittig, C.; Hirt, H.P.; Buser, D. Biomechanical comparison of the sandblasted and acid-etched and the machined and acid-etched titanium surface for dental implants. J. Biomed. Mater. Res. 2002, 60, 325-332. [CrossRef]

91. Roehling, S.K.; Meng, B.; Cochran, D.L. Sandblasted and Acid-Etched Implant Surfaces with or without High Surface Free Energy: Experimental and Clinical Background BT. In Implant Surfaces and Their Biological and Clinical Impact; Wennerberg, A., Albrektsson, T., Jimbo, R., Eds.; Springer: Berlin/Heidelberg, Germany, 2015; pp. 93-136, ISBN 978-3-662-45379-7.

92. Yang, G.-L.; He, F.-M.; Yang, X.-F.; Wang, X.-X.; Zhao, S.-F. Bone responses to titanium implants surface-roughened by sandblasted and double etched treatments in a rabbit model. Oral Sur. Oral Med. Oral Pathol. Oral Radiol. Endodontol. 2008, 106, 516-524. [CrossRef]

93. Ni, J.; Ling, H.; Zhang, S.; Wang, Z.; Peng, Z.; Benyshek, C.; Zan, R.; Miri, A.K.; Li, Z.; Zhang, X.; et al. Three-dimensional printing of metals for biomedical applications. Mater. Today Bio 2019, 3, 100024. [CrossRef] [PubMed]

94. Tiainen, L.; Abreu, P.; Buciumeanu, M.; Silva, F.; Gasik, M.; Guerrero, R.S.; Carvalho, O. Novel laser surface texturing for improved primary stability of titanium implants. J. Mech. Behav. Biomed. Mater. 2019, 98, 26-39. [CrossRef]

95. Klokkevold, P.R.; Johnson, P.; Dadgostari, S.; Davies, J.E.; Caputo, A.; Nishimura, R.D. Early endosseous integration enhanced by dual acid etching of titanium: A torque removal study in the rabbit. Clin. Oral Implants Res. 2001, 12, 350-357. [CrossRef] [PubMed]

96. Wang, D.; He, G.; Tian, Y.; Ren, N.; Liu, W.; Zhang, X. Dual effects of acid etching on cell responses and mechanical properties of porous titanium with controllable open-porous structure. J. Biomed. Mater. Res. Part B Appl. Biomater. 2020, 108, $2386-2395$. [CrossRef]

97. Szmukler-Moncler, S.; Perrin, D.; Ahossi, V.; Magnin, G.; Bernard, J.P. Biological properties of acid etched titanium implants: Effect of sandblasting on bone anchorage. J. Biomed. Mater. Res. 2004, 68, 149-159. [CrossRef] [PubMed]

98. Yabutsuka, T.; Mizuno, H.; Takai, S. Fabrication of bioactive titanium and its alloys by combination of doubled sandblasting process and alkaline simulated body fluid treatment. J. Ceram. Soc. Jpn. 2019, 127, 669-677. [CrossRef]

99. Baleani, M.; Viceconti, M.; Toni, A. The effect of sandblasting treatment on endurance properties of titanium alloy hip prostheses. Artif. Organs 2000, 24, 296-299. [CrossRef] [PubMed]

100. Li, D.-H.; Liu, B.-L.; Zou, J.-C.; Xu, K.-W. Improvement of osseointegration of titanium dental implants by a modified sandblasting surface treatment. Implant Dent. 1999, 8, 289-294. [CrossRef]

101. Lubas, M. The impact of an innovative sandblasting medium on the titanium-dental porcelain joint. Ceram. Mater. 2019, 71, 276-285.

102. Yuda, A.W.; Supriadi, S.; Saragih, A.S. Surface modification of Ti-alloy based bone implant by sandblasting. In Proceedings of the 4th Biomedical Engineering's Recent Progress in Biomaterials, Drugs Development, Health, and Medical Devices, Padang, Indonesia, 22-24 July 2019; p. 020015.

103. Attarilar, S.; Ebrahimi, M.; Djavanroodi, F.; Fu, Y.; Wang, L.; Yang, J. 3D Printing technologies in metallic implants: A thematic review on the techniques and procedures. Int. J. Bioprint. 2020, 7. [CrossRef]

104. Fousová, M.; Vojtěch, D.; Doubrava, K.; Daniel, M.; Lin, C.-F. Influence of inherent surface and internal defects on mechanical properties of additively manufactured Ti6Al4V alloy: Comparison between selective laser melting and electron beam melting. Materials 2018, 11, 537. [CrossRef]

105. Wang, Q.; Zhou, P.; Liu, S.; Attarilar, S.; Ma, R.L.-W.; Zhong, Y.; Wang, L. Multi-scale surface treatments of titanium implants for rapid osseointegration: A review. Nanomaterials 2020, 10, 1244. [CrossRef]

106. Kunrath, M.F. Customized dental implants: Manufacturing processes, topography, osseointegration and future perspectives of 3D fabricated implants. Bioprinting 2020, 20, e00107. [CrossRef]

107. Srivas, P.K.; Kapat, K.; Dadhich, P.; Pal, P.; Dutta, J.; Datta, P.; Dhara, S. Osseointegration assessment of extrusion printed Ti6Al4V scaffold towards accelerated skeletal defect healing via tissue in-growth. Bioprinting 2017, 6, 8-17. [CrossRef]

108. Wang, H.; Liu, J.; Wang, C.; Shen, S.G.; Wang, X.; Lin, K. The synergistic effect of 3D-printed microscale roughness surface and nanoscale feature on enhancing osteogenic differentiation and rapid osseointegration. J. Mater. Sci. Technol. 2021, 63, 18-26. [CrossRef]

109. Gulati, K.; Prideaux, M.; Kogawa, M.; Lima-Marques, L.; Atkins, G.J.; Findlay, D.M.; Losic, D. Anodized 3D-printed titanium implants with dual micro- and nano-scale topography promote interaction with human osteoblasts and osteocyte-like cells. $J$. Tissue Eng. Regen. Med. 2017, 11, 3313-3325. [CrossRef] 
110. Baker, T. Laser surface modification of titanium alloys. In Surface Engineering of Light Alloys; Elsevier: Amsterdam, The Netherlands, 2010; pp. 398-443.

111. Kurella, A.; Dahotre, N.B. Review paper: Surface modification for bioimplants: The role of laser surface engineering. J. Biomater. Appl. 2005, 20, 5-50. [CrossRef]

112. He, A.; Yang, H.; Xue, W.; Sun, K.; Cao, Y. Tunable coffee-ring effect on a superhydrophobic surface. Opt. Lett. 2017, 42, 3936-3939. [CrossRef] [PubMed]

113. Pou, P.; Riveiro, A.; Val, J.; Comesaña, R.; Penide, J.; Arias-González, F.; Sotoa, R.; Lusquiños, F.; Pou, J. Laser surface texturing of Titanium for bioengineering applications. Procedia Manuf. 2017, 13, 694-701. [CrossRef]

114. Mirhosseini, N.; Crouse, P.; Schmidt, M.; Li, L.; Garrod, D. Laser surface micro-texturing of Ti-6Al-4V substrates for improved cell integration. Appl. Surf. Sci. 2007, 253, 7738-7743. [CrossRef]

115. Cunha, A.; Elie, A.-M.; Plawinski, L.; Serro, A.P.; Rego, A.M.B.D.; Almeida, A.; Urdaci, M.C.; Durrieu, M.-C.; Vilar, R. Femtosecond laser surface texturing of titanium as a method to reduce the adhesion of Staphylococcus aureus and biofilm formation. Appl. Surf. Sci. 2016, 360, 485-493. [CrossRef]

116. Chiang, H.-J.; Hsu, H.-J.; Peng, P.-W.; Wu, C.-Z.; Ou, K.-L.; Cheng, H.-Y.; Walinski, C.J.; Sugiatno, E. Early bone response to machined, sandblasting acid etching (SLA) and novel surface-functionalization (SLAffinity) titanium implants: Characterization, biomechanical analysis and histological evaluation in pigs. J. Biomed. Mater. Res. Part A 2016, 104, 397-405. [CrossRef]

117. Liu, R.; Tang, Y.; Liu, H.; Zeng, L.; Ma, Z.; Li, J.; Zhao, Y.; Ren, L.; Yang, K. Effects of combined chemical design (Cu addition) and topographical modification (SLA) of Ti-Cu/SLA for promoting osteogenic, angiogenic and antibacterial activities. J. Mater. Sci. Technol. 2020, 47, 202-215. [CrossRef]

118. Choi, S.-M.; Park, J.-W. Multifunctional effects of a modification of SLA titanium implant surface with strontium-containing nanostructures on immunoinflammatory and osteogenic cell function. J. Biomed. Mater. Res. Part A 2018, 106, 3009-3020. [CrossRef] [PubMed]

119. Kim, B.-S.; Kim, J.S.; Park, Y.M.; Choi, B.-Y.; Lee, J. Mg ion implantation on SLA-treated titanium surface and its effects on the behavior of mesenchymal stem cell. Mater. Sci. Eng. C 2013, 33, 1554-1560. [CrossRef]

120. Bobzin, K.; Ote, M.; Linke, T.F.; Sommer, J.; Liao, X. Influence of process parameter on grit blasting as a pretreatment process for thermal spraying. J. Therm. Spray Technol. 2016, 25, 3-11. [CrossRef]

121. Galvan, J.C.; Saldaña, L.; Multigner, M.; Calzado-Martín, A.; Larrea, M.T.; Serra, C.; Vilaboa, N.; González-Carrasco, J.L. Grit blasting of medical stainless steel: Implications on its corrosion behavior, ion release and biocompatibility. J. Mater. Sci. Mater. Electron. 2012, 23, 657-666. [CrossRef]

122. Ivanoff, C.-J.; Widmark, G.; Hallgren, C.; Sennerby, L.; Wennerberg, A. Histologic evaluation of the bone integration of TiO 2 blasted and turned titanium microimplants in humans. Clin. Oral Implants Res. 2001, 12, 128-134. [CrossRef]

123. Salou, L.; Hoornaert, A.; Louarn, G.; Layrolle, P. Enhanced osseointegration of titanium implants with nanostructured surfaces: An experimental study in rabbits. Acta Biomater. 2015, 11, 494-502. [CrossRef]

124. Kurup, A.; Dhatrak, P.; Khasnis, N. Surface modification techniques of titanium and titanium alloys for biomedical dental applications: A review. Mater. Today Proc. 2021, 39, 84-90. [CrossRef]

125. Smeets, R.; Stadlinger, B.; Schwarz, F.; Beck-Broichsitter, B.; Jung, O.; Precht, C.; Kloss, F.; Gröbe, A.; Heiland, M.; Ebker, T. Impact of dental implant surface modifications on osseointegration. BioMed Res. Int. 2016, 2016, 1-16. [CrossRef] [PubMed]

126. Saghiri, M.; Asatourian, A.; Garcia-Godoy, F.; Sheibani, N. The role of angiogenesis in implant dentistry part I: Review of titanium alloys, surface characteristics and treatments. Med. Oral Patol. Oral Cir. Bucal 2016, 21, e514-e525. [CrossRef] [PubMed]

127. Diomede, F.; Marconi, G.D.; Cavalcanti, M.F.X.B.; Pizzicannella, J.; Pierdomenico, S.D.; Fonticoli, L.; Piattelli, A.; Trubiani, O. VEGF/VEGF-R/RUNX2 Upregulation in human periodontal ligament stem cells seeded on dual acid etched titanium disk. Materials 2020, 13, 706. [CrossRef] [PubMed]

128. Liu, Y.; Luo, D.; Wang, T. Hierarchical structures of bone and bioinspired bone tissue engineering. Small 2016, 12, 4611-4632. [CrossRef]

129. Souza, J.C.; Sordi, M.B.; Kanazawa, M.; Ravindran, S.; Henriques, B.; Silva, F.S.; Aparicio, C.; Cooper, L.F. Nano-scale modification of titanium implant surfaces to enhance osseointegration. Acta Biomater. 2019, 94, 112-131. [CrossRef]

130. Coelho, P.G.; Jimbo, R.; Tovar, N.; Bonfante, E.A. Osseointegration: Hierarchical designing encompassing the macrometer, micrometer, and nanometer length scales. Dent. Mater. 2015, 31, 37-52. [CrossRef] [PubMed]

131. Attarilar, S.; Salehi, M.T.; Al-Fadhalah, K.J.; Djavanroodi, F.; Mozafari, M. Functionally graded titanium implants: Characteristic enhancement induced by combined severe plastic deformation. PLoS ONE 2019, 14, e0221491. [CrossRef] [PubMed]

132. Attarilar, S.; Djavanroodi, F.; Ebrahimi, M.; Al-Fadhalah, K.J.; Wang, L.; Mozafari, M. Hierarchical microstructure tailoring of pure titanium for enhancing cellular response at tissue-implant interface. J. Biomed. Nanotechnol. 2021, 17, 115-130. [CrossRef] [PubMed]

133. Meirelles, L.; Uzumaki, E.T.; Lima, J.H.C.; Lambert, C.S.; Muller, C.A.; Albrektsson, T.; Wennerberg, A. A novel technique for tailored surface modification of dental implants-A step wise approach based on plasma immersion ion implantation. Clin. Oral Implants Res. 2011, 24, 461-467. [CrossRef] [PubMed]

134. Liu, J.; Liu, J.; Attarilar, S.; Wang, C.; Tamaddon, M.; Yang, C.; Xie, K.; Yao, J.; Wang, L.; Liu, C.; et al. Nano-modified titanium implant materials: A way toward improved antibacterial properties. Front. Bioeng. Biotechnol. 2020, 8, 576969. [CrossRef] [PubMed] 
135. Xu, R.; Hu, X.; Yu, X.; Wan, S.; Wu, F.; Ouyang, J.; Deng, F. Micro-/nano-topography of selective laser melting titanium enhances adhesion and proliferation and regulates adhesion-related gene expressions of human gingival fibroblasts and human gingival epithelial cells. Int. J. Nanomed. 2018, 13, 5045-5057. [CrossRef]

136. Mendonca, G.; Mendonça, D.B.; Aragão, F.J.; Cooper, L.F. Advancing dental implant surface technology-From micron-to nanotopography. Biomaterials 2008, 29, 3822-3835. [CrossRef] [PubMed]

137. Yoo, D.; Tovar, N.; Jimbo, R.; Marin, C.; Anchieta, R.B.; Machado, S.; Montclare, J.; Guastaldi, F.P.S.; Janal, M.N.; Coelho, P.G Increased osseointegration effect of bone morphogenetic protein 2 on dental implants: Anin vivostudy. J. Biomed. Mater. Res. Part A 2014, 102, 1921-1927. [CrossRef] [PubMed]

138. Li, X.; Qi, M.; Sun, X.; Weir, M.D.; Tay, F.R.; Oates, T.W.; Dong, B.; Zhou, Y.; Wang, L.; Xu, H.H. Surface treatments on titanium implants via nanostructured ceria for antibacterial and anti-inflammatory capabilities. Acta Biomater. 2019, 94, 627-643. [CrossRef] [PubMed]

139. İzmir, M.; Ercan, B. Anodization of titanium alloys for orthopedic applications. Front. Chem. Sci. Eng. 2019, 13, 28-45. [CrossRef]

140. Yao, C.; Lu, J.; Webster, T.J. Titanium and cobalt-chromium alloys for hips and knees. In Biomaterials for Artificial Organs; Elsevier: Amsterdam, The Netherlands, 2011; pp. 34-55.

141. Minagar, S.; Berndt, C.C.; Wang, J.; Ivanova, E.; Wen, C. A review of the application of anodization for the fabrication of nanotubes on metal implant surfaces. Acta Biomater. 2012, 8, 2875-2888. [CrossRef] [PubMed]

142. Wang, Q.; Huang, J.-Y.; Li, H.-Q.; Zhao, A.Z.-J.; Wang, Y.; Zhang, K.-Q.; Sun, H.-T.; Lai, Y.-K. Recent advances on smart TiO 2 nanotube platforms for sustainable drug delivery applications. Int. J. Nanomed. 2016, 12, 151-165. [CrossRef] [PubMed]

143. Peng, L.; Mendelsohn, A.D.; LaTempa, T.J.; Yoriya, S.; Grimes, C.A.; Desai, T.A. Long-term small molecule and protein elution from $\mathrm{TiO}_{2}$ nanotubes. Nano Lett. 2009, 9, 1932-1936. [CrossRef] [PubMed]

144. Setyawati, M.I.; Sevencan, C.; Bay, B.H.; Xie, J.; Zhang, Y.; Demokritou, P.; Leong, D.T. Nano-TiO 2 drives epithelial-mesenchymal transition in intestinal epithelial cancer cells. Small 2018, 14, e1800922. [CrossRef]

145. Linklater, D.P.; Baulin, V.A.; Juodkazis, S.; Crawford, R.J.; Stoodley, P.; Ivanova, E.P. Mechano-bactericidal actions of nanostructured surfaces. Nat. Rev. Genet. 2021, 19, 8-22. [CrossRef]

146. Smith, Y.R.; Ray, R.S.; Carlson, K.; Sarma, B.; Misra, M. Self-ordered titanium dioxide nanotube arrays: Anodic synthesis and their photo/electro-catalytic applications. Materials 2013, 6, 2892-2957. [CrossRef] [PubMed]

147. Fu, Y.; Mo, A. A review on the electrochemically self-organized titania nanotube arrays: Synthesis, modifications, and biomedical applications. Nanoscale Res. Lett. 2018, 13, 1-21. [CrossRef]

148. Wang, N.; Li, H.; Lü, W.; Li, J.; Wang, J.; Zhang, Z.; Liu, Y. Effects of $\mathrm{TiO}_{2}$ nanotubes with different diameters on gene expression and osseointegration of implants in minipigs. Biomaterials 2011, 32, 6900-6911. [CrossRef]

149. Su, E.P.; Justin, D.F.; Pratt, C.R.; Sarin, V.K.; Nguyen, V.S.; Oh, S.; Jin, S. Effects of titanium nanotubes on the osseointegration, cell differentiation, mineralisation and antibacterial properties of orthopaedic implant surfaces. Bone Jt. J. 2018, 100-B, 9-16. [CrossRef]

150. Choi, W.-Y.; Lee, J.-K.; Choi, D.-S.; Jang, I. Improved osseointegration of dental titanium implants by TiO $\mathrm{T}_{2}$ nanotube arrays with recombinant human bone morphogenetic protein-2: A pilot in vivo study. Int. J. Nanomed. 2015, 10, 1145-1154. [CrossRef] [PubMed]

151. Hu, N.; Wu, Y.; Xie, L.; Yusuf, S.M.; Gao, N.; Starink, M.J.; Tong, L.; Chu, P.K.; Wang, H. Enhanced interfacial adhesion and osseointegration of anodic $\mathrm{TiO}_{2}$ nanotube arrays on ultra-fine-grained titanium and underlying mechanisms. Acta Biomater. 2020, 106, 360-375. [CrossRef] [PubMed]

152. Sargin, F.; Erdogan, G.; Kanbur, K.; Turk, A. Investigation of in vitro behavior of plasma sprayed $\mathrm{Ti}_{\text {, }} \mathrm{TiO}_{2}$ and $\mathrm{HA}_{\mathrm{A}}$ coatings on PEEK. Surf. Coat. Technol. 2021, 411, 126965. [CrossRef]

153. Lee, B.-H.; Kim, J.K.; Kim, Y.D.; Choi, K.; Lee, K.H. In vivo behavior and mechanical stability of surface-modified titanium implants by plasma spray coating and chemical treatments. J. Biomed. Mater. Res. 2004, 69, 279-285. [CrossRef]

154. Singh, H.; Kumar, R.; Prakash, C.; Singh, S. HA-based coating by plasma spray techniques on titanium alloy for orthopedic applications. Mater. Today Proc. 2021. [CrossRef]

155. Roy, M.; Balla, V.K.; Bandyopadhyay, A.; Bose, S. Compositionally graded hydroxyapatite/tricalcium phosphate coating on Ti by laser and induction plasma. Acta Biomater. 2011, 7, 866-873. [CrossRef] [PubMed]

156. Van Oirschot, B.A.J.A.; Bronkhorst, E.; van den Beucken, J.J.J.P.; Meijer, G.J.; Jansen, J.A.; Junker, R. A systematic review on the long-term success of calcium phosphate plasma-spray-coated dental implants. Odontology 2016, 104, 347-356. [CrossRef]

157. Li, B.; Liu, X.; Meng, F.; Chang, J.; Ding, C. Preparation and antibacterial properties of plasma sprayed nano-titania/silver coatings. Mater. Chem. Phys. 2009, 118, 99-104. [CrossRef]

158. Khor, K.; Gu, Y.; Quek, C.; Cheang, P. Plasma spraying of functionally graded hydroxyapatite/Ti-6Al-4V coatings. Surf. Coat. Technol. 2003, 168, 195-201. [CrossRef]

159. Singh, H.; Rana, P.K.; Singh, J.; Singh, S.; Prakash, C.; Królczyk, G. Plasma Spray Deposition of HA-TiO 2 Composite Coating on Ti-6Al-4V Alloy for Orthopedic Applications. In Advances in Materials Processing; Singh, S., Prakash, C., Ramakrishna, S., Krolczyk, G., Eds.; Springer: Singapore, 2020; pp. 13-20, ISBN 978-981-15-4748-5.

160. Hameed, P.; Gopal, V.; Bjorklund, S.; Ganvir, A.; Sen, D.; Markocsan, N.; Manivasagam, G. Axial suspension plasma spraying: An ultimate technique to tailor Ti6Al4V surface with HAp for orthopaedic applications. Colloids Surf. B Biointerfaces 2019, 173, 806-815. [CrossRef] 
161. Dietsch, R.; Holz, T.; Mai, H.; Panzner, M.; Völlmar, S. Pulsed laser deposition (PLD)—An advanced state for technical applications. Opt. Quantum Electron. 1995, 27, 1385-1396. [CrossRef]

162. Prasanna, S.R.V.S.; Balaji, K.; Pandey, S.; Rana, S. Metal Oxide Based Nanomaterials and Their Polymer Nanocomposites. In Nanomaterials and Polymer Nanocomposites; Elsevier: Amsterdam, The Netherlands, 2019; pp. 123-144.

163. Duta, L. In vivo assessment of synthetic and biological-derived calcium phosphate-based coatings fabricated by pulsed laser deposition: A review. Coatings 2021, 11, 99. [CrossRef]

164. Galindo-Valdés, J.; Cortés-Hernández, D.; Ortiz-Cuellar, J.; De la O-Baquera, E.; Escobedo-Bocardo, J.; Acevedo-Dávila, J. Laser deposition of bioactive coatings by in situ synthesis of pseudowollastonite on Ti6Al4V alloy. Opt. Laser Technol. 2021, 134, 106586. [CrossRef]

165. Cao, J.; Lian, R.; Jiang, X.; Rogachev, A.V. In vitro degradation assessment of calcium fluoride-doped hydroxyapatite coating prepared by pulsed laser deposition. Surf. Coat. Technol. 2021, 416, 127177. [CrossRef]

166. Cao, J.; Lian, R.; Jiang, X. Magnesium and fluoride doped hydroxyapatite coatings grown by pulsed laser deposition for promoting titanium implant cytocompatibility. Appl. Surf. Sci. 2020, 515, 146069. [CrossRef]

167. Zaveri, N.; Mahapatra, M.; Deceuster, A.; Peng, Y.; Li, L.; Zhou, A. Corrosion resistance of pulsed laser-treated Ti-6Al-4V implant in simulated biofluids. Electrochim. Acta 2008, 53, 5022-5032. [CrossRef]

168. Vishwakarma, V.; Josephine, J.; George, R.P.; Krishnan, R.; Dash, S.; Kamruddin, M.; Kalavathi, S.; Manoharan, N.; Tyagi, A.K.; Dayal, R.K. Antibacterial copper-nickel bilayers and multilayer coatings by pulsed laser deposition on titanium. Biofouling 2009, 25, 705-710. [CrossRef]

169. Rajesh, P.; Mohan, N.; Yokogawa, Y.; Varma, H. Pulsed laser deposition of hydroxyapatite on nanostructured titanium towards drug eluting implants. Mater. Sci. Eng. C 2013, 33, 2899-2904. [CrossRef]

170. Chen, L.; Komasa, S.; Hashimoto, Y.; Hontsu, S.; Okazaki, J. In vitro and in vivo osteogenic activity of titanium implants coated by pulsed laser deposition with a thin film of fluoridated hydroxyapatite. Int. J. Mol. Sci. 2018, 19, 1127. [CrossRef] [PubMed]

171. Pelletier, H.; Nelea, V.; Mille, P.; Muller, D. Mechanical properties of pulsed laser-deposited hydroxyapatite thin film implanted at high energy with $\mathrm{N}+$ and Ar+ ions. Part I: Nanoindentation with spherical tipped indenter. Nucl. Instrum. Methods Phys. Res. Sect. B Beam Interact. Mater. At. 2004, 216, 269-274. [CrossRef]

172. Duta, L.M.; Oktar, F.; Stan, G.; Popescu-Pelin, G.; Serban, N.; Luculescu, C.; Mihailescu, I. Novel doped hydroxyapatite thin films obtained by pulsed laser deposition. Appl. Surf. Sci. 2013, 265, 41-49. [CrossRef]

173. Mihailescu, I.N.; Ristoscu, C.; Bigi, A.; Mayer, I. Advanced Biomimetic Implants Based on Nanostructured Coatings Synthe-sized by Pulsed Laser Technologies. In Laser-Surface Interactions for New Materials Production; Springer: New York, NY, USA, 2010; pp. 235-260.

174. Vijayan, P.P.; Puglia, D. Biomimetic multifunctional materials: A review. Emergent Mater. 2019, 2, 391-415. [CrossRef]

175. Han, Z.; Mu, Z.; Yin, W.; Li, W.; Niu, S.; Zhang, J.; Ren, L. Biomimetic multifunctional surfaces inspired from animals. Adv. Colloid Interface Sci. 2016, 234, 27-50. [CrossRef]

176. Spriano, S.; Yamaguchi, S.; Baino, F.; Ferraris, S. A critical review of multifunctional titanium surfaces: New frontiers for improving osseointegration and host response, avoiding bacteria contamination. Acta Biomater. 2018, 79, 1-22. [CrossRef] [PubMed]

177. Spriano, S.; Ferraris, S.; Pan, G.; Cassinelli, C.; Vernè, E. Multifunctional titanium: Surface modification process and biological response. J. Mech. Med. Biol. 2015, 15, 1540001. [CrossRef]

178. Liu, X.; Zhao, X.; Fu, R.K.; Ho, J.P.; Ding, C.; Chu, P.K. Plasma-treated nanostructured $\mathrm{TiO}_{2}$ surface supporting biomimetic growth of apatite. Biomaterials 2005, 26, 6143-6150. [CrossRef] [PubMed]

179. Gulati, K.; Ramakrishnan, S.; Aw, M.S.; Atkins, G.J.; Findlay, D.M.; Losic, D. Biocompatible polymer coating of titania nanotube arrays for improved drug elution and osteoblast adhesion. Acta Biomater. 2012, 8, 449-456. [CrossRef] [PubMed]

180. Xu, D.; Yang, W.; Hu, Y.; Luo, Z.; Li, J.; Hou, Y.; Liu, Y.; Cai, K. Surface functionalization of titanium substrates with cecropin B to improve their cytocompatibility and reduce inflammation responses. Colloids Surf. B Biointerfaces 2013, 110, 225-235. [CrossRef]

181. Zhou, L.; Lin, Z.; Ding, J.; Huang, W.; Chen, J.; Wu, D. Inflammatory and biocompatibility evaluation of antimicrobial peptide GL13K immobilized onto titanium by silanization. Colloids Surf. B Biointerfaces 2017, 160, 581-588. [CrossRef]

182. Nie, B.; Long, T.; Li, H.; Wang, X.; Yue, B. A comparative analysis of antibacterial properties and inflammatory responses for the KR-12 peptide on titanium and PEGylated titanium surfaces. RSC Adv. 2017, 7, 34321-34330. [CrossRef]

183. Wang, L.; Xie, L.; Shen, P.; Fan, Q.; Wang, W.; Wang, K.; Lu, W.; Hua, L.; Zhang, L.-C. Surface microstructure and mechanical properties of Ti-6Al-4V/Ag nanocomposite prepared by FSP. Mater. Charact. 2019, 153, 175-183. [CrossRef]

184. Li, P.; Li, X.; Cai, W.; Chen, H.; Chen, H.; Wang, R.; Zhao, Y.; Wang, J.; Huang, N. Phospholipid-based multifunctional coating via layer-by-layer self-assembly for biomedical applications. Mater. Sci. Eng. C 2020, 116, 111237. [CrossRef]

185. Venkateswarlu, K.; Rameshbabu, N.; Bose, A.C.; Muthupandi, V.; Subramanian, S.; MubarakAli, D.; Thajuddin, N. Fabrication of corrosion resistant, bioactive and antibacterial silver substituted hydroxyapatite/titania composite coating on Cp Ti. Ceram. Int. 2012, 38, 731-740. [CrossRef]

186. Singh, R.K.; Awasthi, S.; Dhayalan, A.; Ferreira, J.; Kannan, S. Deposition, structure, physical and invitro characteristics of Ag-doped $\beta$-Ca3(PO4)2/chitosan hybrid composite coatings on Titanium metal. Mater. Sci. Eng. C 2016, 62, 692-701. [CrossRef] [PubMed] 
187. Zhang, X.; Wang, H.; Li, J.; He, X.; Hang, R.; Huang, X.; Tian, L.; Tang, B. Corrosion behavior of Zn-incorporated antibacterial $\mathrm{TiO}_{2}$ porous coating on titanium. Ceram. Int. 2016, 42, 17095-17100. [CrossRef]

188. Zhang, X.; Li, J.; Wang, X.; Wang, Y.; Hang, R.; Huang, X.; Tang, B.; Chu, P.K. Effects of copper nanoparticles in porous TiO 2 coatings on bacterial resistance and cytocompatibility of osteoblasts and endothelial cells. Mater. Sci. Eng. C 2018, 82, 110-120. [CrossRef] [PubMed]

189. Jia, Z.; Xiu, P.; Li, M.; Xu, X.; Shi, Y.; Cheng, Y.; Wei, S.; Zheng, Y.; Xi, T.; Cai, H.; et al. Bioinspired anchoring AgNPs onto micro-nanoporous $\mathrm{TiO}_{2}$ orthopedic coatings: Trap-killing of bacteria, surface-regulated osteoblast functions and host responses. Biomaterials 2016, 75, 203-222. [CrossRef]

190. Roknian, M.; Fattah-Alhosseini, A.; Gashti, S.O.; Keshavarz, M.K. Study of the effect of ZnO nanoparticles addition to PEO coatings on pure titanium substrate: Microstructural analysis, antibacterial effect and corrosion behavior of coatings in Ringer's physiological solution. J. Alloys Compd. 2018, 740, 330-345. [CrossRef]

191. Gokcekaya, O.; Webster, T.J.; Ueda, K.; Narushima, T.; Ergun, C. In vitro performance of Ag-incorporated hydroxyapatite and its adhesive porous coatings deposited by electrostatic spraying. Mater. Sci. Eng. C 2017, 77, 556-564. [CrossRef]

192. El-Rab, S.M.G.; Fadl-Allah, S.A.; Montser, A. Improvement in antibacterial properties of Ti by electrodeposition of biomimetic Ca-P apatite coat on anodized titania. Appl. Surf. Sci. 2012, 261, 1-7. [CrossRef]

193. Huang, Y.; Wang, W.; Zhang, X.; Liu, X.; Xu, Z.; Han, S.; Su, Z.; Liu, H.; Gao, Y.; Yang, H. A prospective material for orthopedic applications: Ti substrates coated with a composite coating of a titania-nanotubes layer and a silver-manganese-doped hydroxyapatite layer. Ceram. Int. 2018, 44, 5528-5542. [CrossRef]

194. Zhang, X.; Chaimayo, W.; Yang, C.; Yao, J.; Miller, B.L.; Yates, M.Z. Silver-hydroxyapatite composite coatings with enhanced antimicrobial activities through heat treatment. Surf. Coat. Technol. 2017, 325, 39-45. [CrossRef]

195. Geng, Z.; Cui, Z.; Li, Z.; Zhu, S.; Liang, Y.; Liu, Y.; Li, X.; He, X.; Yu, X.; Wang, R.; et al. Strontium incorporation to optimize the antibacterial and biological characteristics of silver-substituted hydroxyapatite coating. Mater. Sci. Eng. C 2016, 58, 467-477. [CrossRef] [PubMed]

196. Muhaffel, F.; Cempura, G.; Menekse, M.; Czyrska-Filemonowicz, A.; Karaguler, N.; Cimenoglu, H. Characteristics of multi-layer coatings synthesized on Ti6Al4V alloy by micro-arc oxidation in silver nitrate added electrolytes. Surf. Coat. Technol. 2016, 307, 308-315. [CrossRef]

197. Wang, R.; He, X.; Gao, Y.; Zhang, X.; Yao, X.; Tang, B. Antimicrobial property, cytocompatibility and corrosion resistance of $\mathrm{Zn}$-doped $\mathrm{ZrO}_{2} / \mathrm{TiO}_{2}$ coatings on Ti6Al4V implants. Mater. Sci. Eng. C 2017, 75, 7-15. [CrossRef]

198. Chozhanathmisra, M.; Ramya, S.; Kavitha, L.; Gopi, D. Development of zinc-halloysite nanotube/minerals substituted hydroxyapatite bilayer coatings on titanium alloy for orthopedic applications. Colloids Surf. A Physicochem. Eng. Asp. 2016, 511, 357-365. [CrossRef]

199. Patiño-Herrera, R.; González-Alatorre, G.; Estrada-Baltazar, A.; Escoto-Chavéz, S.; Pérez, E. Hydrophobic coatings for prevention of dental enamel erosion. Surf. Coat. Technol. 2015, 275, 148-154. [CrossRef]

200. Tetz, M.; Jorgensen, M.R. New hydrophobic IOL materials and understanding the science of glistenings. Curr. Eye Res. 2015, 40, 969-981. [CrossRef] [PubMed]

201. Ma, N.; Chen, Y.; Zhao, S.; Li, J.; Shan, B.; Sun, J. Preparation of super-hydrophobic surface on Al-Mg alloy substrate by electrochemical etching. Surf. Eng. 2019, 35, 394-402. [CrossRef]

202. Bains, D.; Singh, G.; Kaur, N.; Singh, N. Development of an ionic liquid metal-based nanocomposite-loaded hierarchical hydrophobic surface to the aluminum substrate for antibacterial properties. ACS Appl. Bio Mater. 2020, 3, 4962-4973. [CrossRef]

203. Zhang, D.; Yuan, T.; Wei, G.; Wang, H.; Gao, L.; Lin, T. Preparation of self-healing hydrophobic coating on AA6061 alloy surface and its anti-corrosion property. J. Alloys Compd. 2019, 774, 495-501. [CrossRef]

204. Tang, P.; Zhang, W.; Wang, Y.; Zhang, B.; Wang, H.; Lin, C.; Zhang, L. Effect of superhydrophobic surface of titanium on Staphylococcus aureus adhesion. J. Nanomater. 2011, 2011, 1-8. [CrossRef]

205. Zhang, X.; Wan, Y.; Ren, B.; Wang, H.; Yu, M.; Liu, A.; Liu, Z. Preparation of superhydrophobic surface on titanium alloy via micro-milling, anodic oxidation and fluorination. Micromachines 2020, 11, 316. [CrossRef] [PubMed]

206. Li, S.; Zhang, T.; Zhou, M.; Zhang, X.; Gao, Y.; Cai, X. A novel digital and visualized guided bone regeneration procedure and digital precise bone augmentation: A case series. Clin. Implant Dent. Relat. Res. 2021, 23, 19-30. [CrossRef] [PubMed]

207. Yin, S.; Zhang, W.; Tang, Y.; Yang, G.; Wu, X.; Lin, S.; Liu, X.; Cao, H.; Jiang, X. Preservation of alveolar ridge height through mechanical memory: A novel dental implant design. Bioact. Mater. 2021, 6, 75-83. [CrossRef] [PubMed]

208. Momeni, F.; Hassani, S.M.; Liu, X.; Ni, J. A review of 4D printing. Mater. Des. 2017, 122, 42-79. [CrossRef]

209. Javaid, M.; Haleem, A. 4D printing applications in medical field: A brief review. Clin. Epidemiol. Glob. Health 2019, 7, 317-321. [CrossRef]

210. Khorsandi, D.; Fahimipour, A.; Abasian, P.; Saber, S.S.; Seyedi, M.; Ghanavati, S.; Ahmad, A.; De Stephanis, A.A.; Taghavinezhaddilami, F.; Leonova, A.; et al. 3D and 4D printing in dentistry and maxillofacial surgery: Printing techniques, materials, and applications. Acta Biomater. 2021, 122, 26-49. [CrossRef] [PubMed]

211. Zarek, M.; Mansour, N.; Shapira, S.; Cohn, D. 4D Printing of shape memory-based personalized endoluminal medical devices. Macromol. Rapid Commun. 2017, 38, 1600628. [CrossRef]

212. Banks, J. Adding value in additive manufacturing: Researchers in the United Kingdom and Europe look to 3D printing for customization. IEEE Pulse 2013, 4, 22-26. [CrossRef] 
213. Zhang, C.; Cai, D.; Liao, P.; Su, J.-W.; Deng, H.; Vardhanabhuti, B.; Ulery, B.D.; Chen, S.-Y.; Lin, J. 4D Printing of shape-memory polymeric scaffolds for adaptive biomedical implantation. Acta Biomater. 2021, 122, 101-110. [CrossRef] [PubMed]

214. Lin, C.; Zhang, L.; Liu, Y.; Liu, L.; Leng, J. 4D printing of personalized shape memory polymer vascular stents with negative Poisson's ratio structure: A preliminary study. Sci. China Ser. E Technol. Sci. 2020, 63, 578-588. [CrossRef]

215. Azam, A.; Laflin, K.E.; Jamal, M.; Fernandes, R.; Gracias, D.H. Self-folding micropatterned polymeric containers. Biomed. Microdevices 2011, 13, 51-58. [CrossRef]

216. Lukin, I.; Musquiz, S.; Erezuma, I.; Al-Tel, T.H.; Golafshan, N.; Dolatshahi-Pirouz, A.; Orive, G. Can 4D bioprinting revolutionize drug development? Expert Opin. Drug Discov. 2019, 14, 953-956. [CrossRef] [PubMed]

217. Melocchi, A.; Uboldi, M.; Inverardi, N.; Vangosa, F.B.; Baldi, F.; Pandini, S.; Scalet, G.; Auricchio, F.; Cerea, M.; Foppoli, A.; et al. Expandable drug delivery system for gastric retention based on shape memory polymers: Development via $4 \mathrm{D}$ printing and extrusion. Int. J. Pharm. 2019, 571, 118700. [CrossRef] [PubMed]

218. Evdokimov, P.V.; Putlayev, V.I.; Orlov, N.K.; Tikhonov, A.A.; Tikhonova, S.A.; Garshev, A.V.; Milkin, P.A.; Klimashina, E.S.; Zuev, D.M.; Filippov, Y.Y.; et al. Adaptable metamaterials based on biodegradable composites for bone tissue regeneration. Inorg. Mater. Appl. Res. 2021, 12, 404-415. [CrossRef]

219. Hashemi, M.S.; McCrary, A.; Kraus, K.H.; Sheidaei, A. A novel design of printable tunable stiffness metamaterial for bone healing. J. Mech. Behav. Biomed. Mater. 2021, 116, 104345. [CrossRef]

220. Ghavidelnia, N.; Bodaghi, M.; Hedayati, R. Femur auxetic meta-implants with tuned micromotion distribution. Materials 2020, 14, 114. [CrossRef] [PubMed]

221. Kolken, H.; de Jonge, C.; van der Sloten, T.; Garcia, A.F.; Pouran, B.; Willemsen, K.; Weinans, H.; Zadpoor, A. Additively manufactured space-filling meta-implants. Acta Biomater. 2021, 125, 345-357. [CrossRef] 